\title{
Livros de viagem do Oitocentos e a fabricação do Oriente: a Índia e a escrita em Maria Graham
}

\author{
Margareth de Almeida Gonçalves
}

A escritora Maria Graham (1785-1842), Dundas de nascimento, filha de um oficial naval escocês e de uma americana realista, foi à Índia aos 23 anos. Embarcou na fragata real Cornelia, em 30 de dezembro de 1808, na companhia do pai, George Dundas, designado comissionário da Marinha Real em Bombaim, de sua irmã Agnes e do irmão mais novo, Ralph. ${ }^{1}$ As linhas iniciais de Journal of a Residence in India, publicado em 1812, são pontuadas pelas primeiras impressões sobre a estada de dois anos na Índia britânica. Na chegada a Bombaim, em 26 de maio de 1809, após cinco meses a bordo, um denso nevoeiro anunciava a entrada da temporada de monções no subcontinente indiano. ${ }^{2}$ No cais, liteiras, palankeens, operavam o deslocamento para terra firme. A narrativa prossegue, descrevendo o hamul, termo utilizado para o condutor de palanquim, que possuía apenas de veste um turbante que cobria a cabeça, mas que a coloração escura da pele, para o olhar europeu, produzia o efeito de vestir o corpo nu. O ritmo frenético de pessoas e carruagens que se misturavam fornecia o cenário que um pintor estudaria ao detalhe na composição do quadro. A metáfora da pintura forma o leitmotif do livro que transfere para a escrita o entusiasmo do pintor romântico em realçar detalhes de hábitos, costumes, comportamentos e da paisagem indiana. O relato de Maria Graham apreende vestígios, sobras, que recordam um triunfo pretérito, como no exemplo das mulheres nativas na beira do gate de Bombaim que graciosamente guardam a leveza de antigas esculturas. O colecionador-escritor captura no presente as lembranças de um passado adormecido.

Journal of a Residence in India é o primeiro de uma sucessão de livros de Graham em que os relatos de viagem formam um conjunto que, entre 1812 e 1825, acompanhou a sequência do itinerário de configuração do capitalismo britânico: hegemonia econômica britânica no Oriente da Índia e os novos países que emergiam das antigas Américas espanhola e portuguesa. De Journal of a Residence in India e Letters on India aos diários de viagem sobre Chile e Brasil, entre 1812 e 1824, período de edição das quatro obras, sucedia a ampliação da fronteira de dominação e influência do capitalismo inglês. Um período ocupado pelas guerras napoleônicas e o frágil equilíbrio de uma nova ordem, após a derrota de Napoleão e seu exílio de 1815 em Santa Helena. Uma fase de fluxos e hiatos, em que novas formas de estado, economia e ideologia se anunciavam. ${ }^{3}$

As disputas pela posição de liderança e potência entre Inglaterra e França espalharam-se na segunda metade do Setecentos por regiōes distantes como América e Ásia. A perda das colônias inglesas com a independência dos Estados Unidos deslocou o enfrentamento para o leste. Segundo Simon Schama, já antes do Tratado de Versailles, em 1783, reconhecendo a independência dos estados americanos, a França retornava à Índia para patrocinar o sultão de Mysore na guerra contra os britânicos. ${ }^{4}$ A East India Company, que se destacava como empresa comercial e de base territorial no subcontinente indiano, numa fase da pré-história do imperialismo britânico, enfrentava a dura e severa crítica no parlamento inglês na perspicaz e caudalosa retórica de Edmund Burke (1729-1797), que resultou no impeachment de Warren Hastings (1732-1818) no governo geral da Índia britânica. O afastamento do governador geral exemplifica o dilema entre corrupção e virtude que atravessou o pensamento político escocês e inglês do século XVIII. É oportuno lembrar que os britânicos experimentavam um "momento maquiaveliano", na expressão de John Poccock, ${ }^{5}$ na crise que afetava a polêmica entre corrupção e virtude. Na acepção da virtus renascentista, a Índia, com seu longo legado civilizatório, esvaía-se na cobiça e no oportunismo do que era entendido como a rapina mercantil ambiciosa pelo lucro. As companhias de 
comércio eram entendidas como ameaças ao sentido de liberdade que na perspectiva lockiana identifica-se à noção lata da propriedade privada. Na defesa última do esteio do humanismo cívico da comunidade aristotélica, a dimensão da moral política denunciava a pujança ostensiva e a crueldade da East India Company com os nativos indianos. ${ }^{6}$

No cenário político e econômico inglês, a segunda metade do século XVIII, assinalou, após a perda das 13 colônias americanas com a guerra de independência, a expansão da Companhia das Índias Orientais na Ásia e o desenho do futuro Império Britânico do Oitocentos. As gerações das décadas finais do século XVIII enfrentaram questões e debates da agenda política, já presentes desde o início do século XVIII, sobre as ameaças e os custos da expansão territorial para a metrópole. A discussão do tema da corrupção desdobrou-se em tópicos sobre os riscos da escravidão, o despotismo oriental, a liberdade dos ingleses, debates que implicavam a discussão acerca do status da cidadania no centro e na periferia do Império.

Após a independência americana, o eixo de gravidade britânico deslocou-se do Atlântico para o Oceano Índico. ${ }^{7} \mathrm{Na}$ região indiana, a afirmação britânica foi fortalecida após o fim dos reinos que sucederam aos mongóis em Bengala, Bihar e Orissa, anunciando uma nova época da atuação da East India Company que, em Calcutá, formou o epicentro político, econômico e da produção de conhecimento sobre o mundo indiano. A segunda metade do século XVIII assegurou a crescente presença britânica nas regiões da costa indiana ocidental e oriental, de Guzerate, Malabar, do Coromandel, e após a tomada aos franceses de Pondichéry em 1761, Bengala. ${ }^{8} \mathrm{O}$ avanço inglês no espaço asiático prefigurava o Raj Britânico na Índia do reinado da rainha Vitória. Na historiografia sobre o império inglês tornou-se consensual uma divisão entre o antigo, primeiro império britânico, o do eixo do Atlântico e o subsequente, o segundo império britânico do século XIX, de expansão através da Ásia, África e Australasia.?

Esse amplo painel situa os livros de viagem de Maria Graham, em que o deslocamento pelo espaço não europeu foi facilitado pela condição de filha e esposa de oficiais da Real Marinha Britânica. Este artigo trata dos usos da representação do outro pela ótica das relaçôes de poder, gênero e cultura na estrutura das narrativas de viagem sobre o Oriente. Focalizam-se as visōes e as percepçōes produtoras de memória e imaginação, através da experiência da observação diletante do viajante e seu enquadramento aos protocolos de escrita do livro de viagem. Propóe-se, assim, entender o relato de viagem como um tradutor de culturas, de possibilidades de encontros que se realizam nas fronteiras da dinâmica colonial e imperial. O eu viajante do narrador opera no lugar de intermediação e da negociação entre culturas, como também da divulgação pela escrita dos inúmeros desafios dos embates entre as experiências do estrangeiro e o nativo.

\section{Livros de viagem e mundos letrados}

$\mathrm{Na}$ esteira do avanço da primeira industrialização, os viajantes europeus, homens e mulheres em menor número, acionaram e intensificaram a tradução e a troca simbólica entre culturas e regiōes fora do raio europeu. $\mathrm{Na}$ perspectiva do universo europeu, em que a mudança constitui a chave do progresso, a passagem por regiōes como Índia, Brasil e Chile, que pareciam ao olhar inglês reminiscências de um longo sono arcaico, faz do viajante o ventríloquo do novo tempo. Graham é esse exemplo de personagem que opera na liminaridade dos processos culturais e de gênero. Contemporânea de Mary Wollstonecraft (1759-1797), autora do célebre The vindication of the rights of men e do também renomado livro de viagens Letters written during a short residence in Sweden, Norway and Denmark (1796), a escrita de viagem de Graham opera nesses interstícios do contínuo deslocamento de códigos e da hibridização cultural. A complexa teia das mediações entre poder, conhecimento, escrita e gênero projeta-se nas figuras diletantes dos viajantes-escritores.

Graham elucida o ritmo de mudanças no padrão de escrita do relato de viagem na transição da ideia de viagem do Gran Tour, do viajante aprendiz para o especialista e cientista e finalmente o viajante-turista da segunda metade do século XIX. Os paradigmas do iluminismo escocês do Setecentos e o romantismo do início do Oitocentos esquadriam a variação cromática do relato de viagem em Graham. 
Esse deslocamento é perceptível nas diferenças do enquadramento narrativo dos livros de viagem sobre a Índia, editados entre 1812 e 1814, e as publicações do Brasil e Chile de 1824.

Em contraste com as viagens de circunavegação de Louis Antoine de Bougainville (1729-1811) e James Cook (1728-1779), no século XVIII, as exploraçōes românticas avançaram para o interior, como são exemplos os relatos sobre os rios Nilo e Niger, na África, dos escoceses James Bruce (1730-1794), autor de Travels to Discover the Source of the Nile, in the Years 1768, 1769, 1770, 1771 and 1773, em seis volumes, o primeiro editado em 1791, e Mungo Park (1771-1806), em Travels in the Interior Districts of Africa: Performed in the Years 1795, 1796, and 1797, publicado, após sua morte, pela renomada editora John Murray, em 1816. ${ }^{10}$

O reconhecimento da opinião pública, ${ }^{11}$ enquanto uma força dinâmica da sociedade, é o corolário da formação de uma modelagem do sujeito e das trocas intersubjetivas, do treinamento dos "sentimentos morais" na acepção de Adam Smith. A emergência de uma percepção do privado, do afeto, das paixões e de uma noção de individualidade produz sujeitos privados no espaço público. ${ }^{12} \mathrm{~A}$ escrita de Maria Graham oferece um caminho de entrada ao universo tempestuoso de uma psicologia interna operada através do delineamento da noção burguesa de indivíduo, do sujeito privado moral em que o culto à educação e leitura provê o aparelhamento interno para atuar e agir no mundo na perspectiva da ascese intramundana da Ética Protestante de Weber.

Foi no panorama setecentista da multiplicação dos espaços públicos e da difusão de uma cultura livresca que se expandiu o mercado de livros de viagem, estimulado pelo surgimento do romance moderno e da contemporânea concepção de literatura. ${ }^{13}$ As publicações de viagem do final do século XVIII e início do Oitocentos exemplificam a reformulação de um gênero na procura por definir critérios de verdade distantes da ficção e fantasia. Etnologia e história oferecem o solo de autenticidade à fidedignidade dos fatos no relato que organiza o pacto autobiográfico. ${ }^{14}$ Por meio dos livros de viagens circulam referências de enquadramento do texto em que a observação testemunhal e a erudição histórica ocupam um lugar central na validação da escrita. Localizam-se indicações das concepções de história dos antigos panoramas das coleções que organizavam as práticas do antiquarismo. Nessa acepção, a expertise é o resultado do acúmulo de conhecimento sobre o passado: os monumentos e as construções arquitetônicas, a arqueologia, os inventários sistemáticos sobre a língua que remetem ao campo da filologia. Segundo Nigel Leask, as narrativas de viagem articulam o discurso estético ao antiquário. O escritor de viagem tece a narrativa por meio da figura do colecionador de fatos e da observação direta.

A escrita de viagem obedece a procedimentos retóricos, em que a observação direta é um mecanismo literário que sedimenta a autoridade do autor. É igualmente central à escrita de viagem setecentista a categoria de experiência na prática pessoal de observação do viajante. ${ }^{15}$ As relações entre conhecimento e experiência, através da leitura e do estudo, firmaram práticas centrais ao pensamento dos vários iluminismos no universo europeu. Os procedimentos retóricos correntes em livros de viagem do início do Oitocentos reproduzem e sistematizam o conhecimento sobre uma tradição já sedimentada dos relatos de viagem no Ocidente que, a partir do século XVII, foi marcada pelo crescimento das casas de edição, dos escritores de guias e livros de viagem e a expansão do letramento e do público leitor.

Maria Graham, na autobiografia que escreveu nos últimos anos de vida, menciona o grand monde que frequentou nas férias durante a infância e a juventude, na casa em Richmond de seu tio David Dundas (1749-1826), médico do rei George III. Richmond, local de lazer da família real, compunha um cenário de vida social, ao final do século XVIII e começo do XIX, pelo qual circulavam literatos, cientistas, artistas e exilados franceses que imigraram após a revolução de 1789. Entre pessoas ilustres, a escrita grahamiana destaca o futuro rei da França Luís Filipe (1830-1848), o "rei cidadão".

$\mathrm{Na}$ fase dos últimos anos de vida, em que a escrita autobiográfica é atenta em atribuir unidade ao sujeito, o relato de Maria Graham valoriza o processo de formação intelectual em que a infância e juventude são descritas como o tempo de desfrute do prazer individual e solitário com a leitura. A atra- 
ção pelo estudo da geografia e o despertar do interesse pelo mundo, para além da fronteira insular, manifestou-se na atração pela escrita de viagem. Nas lembranças que ordena na modulação da narrativa autobiográfica, cita a publicação sobre a viagem à Sibéria realizada pelo francês Jean-Baptiste Chappe d'Auteroche (1722-1769), Voyage en Sibérie fait en 1761. O livro não apenas aguçou, mas provavelmente iniciou o interesse pela fronteira além do leste europeu, tanto a real como a imaginária. ${ }^{16}$ Um Oriente, entretanto, diferente daquele que conheceria na viagem de 1809 à Índia, mas que integrava uma mesma alteridade monolítica, que misturava traços de exotismo e de fascínio, que a projetava no contato com a diversidade de culturas. Mais que os deslocamentos de viagem, os livros introduziam a possibilidade de tradução de outros mundos.

No quadro da disputa sobre a Ásia, a constituição do novo orientalismo e o desenho de uma "geografia imaginativa" do orientalista, enquanto campo autônomo de conhecimento, ganhou impulso. Segundo Edward Said, a invasão do Egito por Napoleão, em 1798, é um marco desse processo de criação do Oriente. França e Inglaterra firmaram-se na posição de vanguarda dos estudos orientalistas. ${ }^{17} \mathrm{~A}$ descoberta do hinduísmo pelas academias britânicas no século XVIII fez emergir um conjunto de estudos especializados que se transformaram em referências clássicas ao universo de conhecimentos sobre a Índia. ${ }^{18}$ No conjunto de estudos sobre o sânscrito e o hinduísmo destacam-se os trabalhos de William Jones $^{19}$ (1726-1794), criador da Asiatic Society of Bengal em 1784, uma versão, segundo Edward Said, da Royal Society da Inglaterra, e Henry Thomas Colebrooke (1765-1837), que foi também presidente e fundador da Sociedade Asiática Real, em 1823. A erudição de ambos atravessa a escrita de Maria Graham, leitora do Asian Researchers, ${ }^{20}$ veículo de divulgação dos estudos sobre a Ásia, patrocinado pela East India Company. É através da letra de Colebrooke que discorre sobre o hinduísmo para o seu leitor.

A Índia que Maria Graham teve contato, longe de constituir uma unidade política, era formada por um mosaico de regiōes e de unidades políticas, que integrava uma larga rede de contatos e interesses, tanto no espaço asiático, quanto na relação com europeus, fossem portugueses, ingleses, franceses ou holandeses. Segundo Sanjay Subrahmanyan, na segunda metade do século XVI e no XVII, os estados asiáticos caracterizam-se por uma fase de transição, de grandes formações agrárias e de pequenos estados mercantis do período anterior a 1500, para um regime intermediário semiagrário e semimercantil, como os exemplos do Irã, de Sá Abbas I, do Estado mongol de Golconda e da Birmânia. O Seiscentos intensificou o confronto e a tensão competitiva entre asiáticos, portugueses e as companhias comerciais da Holanda - Vereenigde Oost-Indische Compagnie (VOC) -, da Inglaterra e de França. Se no século XVII predominou a expansão da VOC, o seguinte assinala o avanço da East India Company. Como já assinalado, a segunda metade do século XVIII marcou a crescente presença britânica nas regiōes da costa ocidental e oriental.

A produção de conhecimento sobre a região da Índia constituiu uma das linhas de investimento da East India Company. Uma década antes de William Jones, no início dos anos de 1770, os orientalistas Charles Wilkins (1749-1836), tradutor para o inglês do Bha,az'id-Gita, Nathaniel Brassey Halhed (1751-1831) e Jonathan Duncan (1756-1811), formaram o campo de estudos sobre Ásia da East India Company. O polêmico presidente da East India Company e primeiro governador-geral da Índia britânica, Warren Hastings, pavimentou o campo orientalista sobre a Índia em Calcutá com a criação da Asiatic Society e do College Fort William. ${ }^{21}$ Como já comentado, nas décadas finais do século XVIII, a tópica da corrupção emerge com contundência, na crise que afetou a Companhia das Índias Orientais e que culminaria no impeachment de Warren Hastings.

Maria Graham publicou dois livros sobre a Índia. Journal of a Residence in Índia teve duas edições sucessivas: a primeira em 1812, e a segunda em 1813, ambas no formato in quarto, com ilustraçôes. ${ }^{22}$ Letters on India, o segundo livro, dividido em 17 cartas, teve uma única edição, de 1814, no formato mais acessível da oitava, também com ilustraçōes e mapa, distribuídos por 419 páginas, incluindo observaçôes sobre as pranchas e uma errata. 
Journal of a Residence in India recebeu ainda uma tradução para o francês em 1818, Journal d'un séjour fait aux Indes Orientales pendant les années 1809,1810 et $1811 .{ }^{23} \mathrm{~A}$ publicação em francês, organizada por cartas, unifica os estilos adotados nos dois livros sobre a Índia, Journal e Letters. O formato epistolar formou um padrão comum em romances ${ }^{24}$ e livros de viagem, em que o amigo imaginário, homem ou mulher, assegura um tom de conversa ao pé do ouvido que autentica a narrativa. O livro manteve o título de Journal, mesmo vocábulo em francês, Journal. Assim, ao longo do Journal d'un séjour... uma mesma carta leva o leitor a acompanhar uma escrita em que se sucedem várias datações do padrão diário. A edição inclui ainda dois prefácios, tradutor e autor, ambos de Maria Graham e, ao final um anexo com glossário de palavras indianas, em quantidade superior à edição em inglês.

O prefácio de Journal of a Residence in India, de autoria provável da própria Graham, informa que a Índia foi visitada por um número significativo de ingleses, o que resultara na edição de inúmeras publicações na área de história militar e política. Desse modo, faltava uma obra em inglês, que adotasse uma perspectiva popular e acessível sobre monumentos, paisagens, comportamentos e hábitos dos nativos e dos colonos residentes. Elogia o mérito de livros objetivos de viagem menos profissionais escritos por observadores ociosos e filosóficos. Adverte que o livro oferece um relato acessível ao público: não se trata de um trabalho de história política e militar, ou mesmo de estudo antiquário de literatura ou mitologia sobre a Índia. Journal of a Residence in India é um livro de viagem para o público em geral. Comenta ainda que a autora deslocou-se ao longo da costa, não penetrando no interior do subcontinente indiano.

O prefácio reproduz a separação entre história política e estudos antiquários. Perpetua-se uma acepção de história da tradição grega, da escrita linear da vida pública, das ações públicas e do homem público, do bios politikos de Aristóteles, de dedicação às questôes político-públicas. ${ }^{25} \mathrm{O}$ Renascimento restabeleceu a divisão greco-romana da história em dois gêneros: a percepção tucidideana de história como política e militar, em que predomina a narrativa linear cronológica dos acontecimentos públicos; e uma segunda, das pesquisas antiquárias que engloba um corpo diversificado de estudos sobre costumes, comportamentos, língua, a cidade, a religião, os monumentos, moedas, ao campo. A longa permanência da separação entre uma acepção da história como narrativa e os estudos antiquários, mais voltados à sistematização do conhecimento, tem um desfecho na confluência entre as duas abordagens, no século XVIII, na constituição do campo científico da história. A obra de Edward Gibbon (1737-94), e seu livro seminal The History of the Decline and Fall of the Roman Empire, é um exemplo dessa superposição. Nesse mesmo período, a variação semântica na língua alemã de Historie e Geschichte aponta para a emergência de uma concepção de história em si, campo autônomo e unificado e que pode ser exemplificada na obra do historiador da arte Johann Joachim Winckelmann (1717-1768). ${ }^{26}$ No entanto, na Grã-Bretanha setecentista, a compreensão da história como história política mantinha não só grande prestígio, como formava o cânon de conhecimento reconhecido como superior e legítimo. O século do pensamento iluminista escocês de David Hume (1711-76), William Robertson (1721-93) e Adam Smith (c.1723-90) tensiona, contudo, o grande gênero da historiografia fundado na preeminência da vida política. A crescente ênfase na vida privada, tanto na dimensão social, quanto da intimidade da casa, corrente em publicações de gêneros variados, mostra um painel que afrouxa as fronteiras entre gêneros tão diversos como história dos costumes, história literária, história religiosa, biografia, memória, romance, literatura de viagem, pesquisa antiquária. ${ }^{27}$ Assim, gêneros como escrita de viagem, biografias, história de costumes produzem efeitos na forma como a história é escrita e objeto de leitura nesse período. Mark Salber Phillips aponta a mudança na construção da narrativa histórica, bifurcada pela subordinação ao cânon clássico da história política linear e a incorporação da dimensão da vida privada na perspectiva de história desenvolvida em Adam Smith nas Lectures on Rhetoric and Belles Lettres. ${ }^{28}$

Uma mutação no aspecto moral da compreensão da vida ocupa um lugar central no pensamento ocidental entre o Renascimento e o Iluminismo, em que o universo intelectual escocês do Setecentos foi uma de suas ramificaçōes. Realiza-se uma revisão dos mecanismos de constituição do sujeito, na 
árdua operação da sinceridade, que ocupa uma posição suprema na vida moral. ${ }^{29} \mathrm{~A}$ construção de si no eu referencial dos livros de Maria Graham indica a emergência de um sujeito psicológico que assegura a autoridade da narrativa e firma o pacto autoral com o leitor. A constituição da História como ciência deu-se, todavia, numa transição em que as fronteiras entre os diversos gêneros de escrita são fluidas e não claramente demarcadas. E os livros de viagem no alvorecer do século XIX apresentam o deslizamento por uma variedade de padrões de escrita que incluem referências ao relato etnográfico, da tradição dos estudos antiquários, à história natural, botânica etc. A tessitura da narrativa apresenta uma relativa liberdade que atende à expansão de um público leitor, para o qual o livro de viagens constitui um instrumento de autoformação, de fruição individual no acesso a temáticas que se associam a uma concepção universal da humanidade e que correspondem a um capital cultural dos novos setores médios da sociedade burguesa. ${ }^{30}$

Desse modo, pelos passos de Maria Graham, a "Índia" é introduzida ao leitor, desde o prefácio. Informa que nossa autora chegou por Bombaim, que formava a terceira presidência britânica na Índia, ${ }^{31}$ em 1809, onde permaneceu os primeiros meses. Entre as curiosidades do entorno da cidade, o prefácio destaca as grutas de Elephanta e de Salsette, ricas em antiguidades, as escavaçôes de Carli, nas montanhas de Mahratta. As duas últimas, acrescenta, registram descobertas recentes. E aqui se acumulam os significados das inúmeras grutas que compunham o cenário religioso de templos brâmanes, jainistas e budistas, que se transformaram num mote clichê de viajantes projetados no estranhamento epifânico de um Oriente inventado pelo Ocidente anglo-saxônico. No século XX, o livro de Edward Morgan Foster, A Passage to India (1924), captura essa atmosfera no drama da personagem Adela, perdida no conjunto das cavernas que compóem a fictícia Marabar.

O relato do prefácio de Journal of a Residence in India desdobra-se na descrição da viagem por Poonah, capital do Império Mahratta. Na volta a Bombaim, nossa viajante passou ao extremo sul em direção ao Ceilão, hoje Sri Lanka, onde chegou pela Ponte de Galle, e deslocou-se à distante Negombo, ao norte da cidade de Colombo, e visitou, na costa leste, a ilha Trincomale na ida para Madras. ${ }^{32}$ Por fim, Calcutá, e o retorno à Inglaterra no começo de 1811, chegando no verão.

O tom do prefácio se destaca pelos elogios, como também discorre sobre a descrição de um padrão de escrita de viagem que valoriza a observação in loco de monumentos, costumes e comportamentos, perpetuando a tradição antiquária na etnologia. $\mathrm{O}$ vocábulo curiosidade é o leitmotif que o prefácio utiliza para os deslocamentos da autora pela Índia.

Lembremos que o périplo pelo território indiano foi pontuado pelo avanço da ação de Thomas Graham, Capitão da Marinha Real, com quem se casou em 9 de dezembro de 1809, seis meses após o desembarque em Bombaim, a 25 de maio. Na passagem em que comenta sobre a geografia do litoral indiano, o prefácio destila uma crítica aos livros de viagem que buscam a autenticidade nativa na descrição de personagens singulares e fantásticos que remetem aos vestígios de uma época de ouro, uma combinação de inocência, benevolência e simplicidade voluptuosa. Esse comentário, atravessado pela ironia, é uma advertência a publicaçôes de viagem; uma crítica ao sentimentalismo oriental, presente no excesso de elementos emotivos na escrita de viajantes. Segundo Nigel Leask, Maria Graham repete uma estratégia de Mary Wollstonecraft em Short Residence in Swede. O alvo da crítica é o livro de Bernardin St. Pierre La Chaumière Indienne. ${ }^{33}$ Ao adotar essa inflexão, Maria Graham assegura a escolha dos procedimentos retóricos que organizam a narrativa. Pontua os elementos de racionalidade intelectual, uma razão não emotiva, que orientam a narrativa sobre a Índia. A posição de autoridade da autora é assegurada no enunciado de procedimentos de organização da escrita que procuram garantir autenticidade e fidelidade aos fatos descritos.

O ponto de vista elogioso do prefácio não se repetiu na crítica do renomado Quarterly Review, que desqualifica a autora com o epíteto de "caçadora de maridos". ${ }^{34}$ Segundo o periódico, Maria Graham, como a maioria das mulheres novas, era movida menos pela informação e a curiosidade e mais pela procura de um marido. Apesar do comentário depreciativo, movido por um enredo de casamento, ${ }^{35}$ a 
crítica no Quarterly Review, do também escritor de livros de viagem John Barrow ${ }^{36}$ (1764-1848), prossegue já em tom menos sarcástico sobre o espaço ocupado pelo Journal no panorama da narrativa de costumes e hábitos das regiōes da Índia. Salpica a ironia ao ressaltar a performance física da autora pelo bom uso que faz das pernas, o que considera prático na Índia. Emprega frases elogiosas à perspicácia da observação. Registra, ainda, que uma auspiciosa Graham se distancia das publicações sobre a Índia que enveredam pela história política e militar. Valoriza a opção pela perspectiva leve do relato sobre os costumes, comportamentos que priorizam a observação do real estado da sociedade indiana e do que chama a atenção de um olhar estrangeiro. O autor da resenha realça a despretensão do livro.

A resenha localiza em Journal of a Residence in India uma leitura leve e justifica a falta de consistência no domínio da expertise e da erudição pela condição de mulher da escritora. As partes do livro que escapam ao relato sobre a paisagem e os costumes e que enveredam por breves ensaios sobre a religião ou filologia na Índia, a resenha não apenas desqualifica como sugere estudos de especialistas. Nos parágrafos em que Maria Graham descreve os Guebres ou Parsees, o soberbo resenhista adverte o leitor que as informações foram obtidas com um monge superior da seita em Bombaim. E aconselha a leitura de Zendavesta de M. Anquetil Du Perron e o Tableau Historique de Chevalier D’Obsson. Indica ainda os artigos de Colebrook na Asiatic Transactions, em substituição à breve exposição da autora sobre os principais deuses do hinduísmo. Após um começo intempestivo, a resenha desdobra-se no formato padrão da época com a reprodução de partes do livro capazes de fornecer ao leitor uma ideia ampla de seu teor.

Assim como o Quarterly Review, também a crítica de The British Review and London Critica ${ }^{77}$ destaca a condição de mulher da autora, já na primeira frase. Ao longo do parágrafo é essa posição e a modéstia da autora, somadas à obrigação do espírito de galanteria masculina do articulista, que organiza a crítica que dá ênfase aos méritos do livro. A despretensão e a inteligência convidam à leitura. As qualidades do livro resultam da capacidade de observação e do relato assistemático da narrativa. Monthly Magazine publica também uma resenha elogiosa a Journal of a Residence in India, destacando a elegância, o gosto e a ponderação correta que marcam cada página da narrativa. Compara o livro a Letters from Constantinople, também escrito por uma mulher, Mary Wortley Montagu. ${ }^{38} \mathrm{~A}$ renomada revista literária escocesa de tendência whig, Edinburgh Review, ignorou ambos os livros sobre a Índia de Graham. ${ }^{39}$

\section{Imaginação sobre a Índia e a matriz indo-europeia}

A estrutura de Journal of a Residence in India segue o padrão do diário, journal, um gênero que se difundiu nas narrativas de viagem. ${ }^{40}$ Como no caso dos Diários sobre a viagem ao Brasil e do Chile, a divisão que dá o ritmo da narrativa é a indicação do dia, mês e local, seguida de observações gerais sobre a paisagem, a cidade, as casas, os habitantes, nativos, traços, hábitos, comportamentos característicos. Contudo, o que é marcante na condução da escrita sobre a Índia é o apoio em referências de especialistas, em que se destacam as atividades de leitura e estudo. ${ }^{41}$ Journal of a Residence in India e Letters on India inscrevem-se na matriz de enquadramento da escrita antiquária, da qual os estudos orientalistas constituem um desdobramento. A modelagem da narrativa combina procedimentos da etnografia, filologia e arqueologia.

Nigel Leask assinala os traços do enquadramento da Índia pitoresca de Maria Graham: o antiutilitarismo, a construção do nativo como curiosidade e a comparação com o que lembra o familiar. O olhar sobre a paisagem indiana é projetado na incansável busca da Escócia e da Inglaterra. A narrativa revela um movimento de viagem pela busca do mesmo. A estrada "pitoresca" e "selvagem" entre as cidades de Chowk e Compowli, no caminho às grutas de Carli, na estrada de Poona, então capital do reino hindu Mahrata, lembram, por exemplo, o cenário do Highland escocês. ${ }^{42} \mathrm{Ou}$ ainda, o familiar na lembrança acolhedora da paisagem doméstica das margens do Tâmisa, frente à beleza do cenário em ruínas dos templos dedicados a Maha Deo e Kali, à beira do rio Hooghly (Bhagirathi), um dos afluentes do Ganges, em Calcutá. ${ }^{43}$ Mais uma vez, a paisagem é percebida pelas lentes do pitoresco que opera o registro por meio de uma concepção do campo no Reino Unido. É o "mesmo" que desperta o olhar sobre a 
alteridade: "Há algo na paisagem deste lugar que me lembra a beleza das margens do Tâmisa: a mesma frescura, a mesma rica folhagem, o mesmo corpo majestoso da água." 44

As descrições de monumentos misturam-se às concepçôes do pitoresco, ${ }^{45}$ na admiração da paisagem e no gosto por ruínas, vestígios do passado. A precisão no levantamento de termos e do vocabulário das línguas, procedimentos presentes no campo do orientalismo, uma ramificação de método da pesquisa antiquária que, como já sugerido, no caso dos estudos ingleses sobre a Índia, tem uma matriz em William Jones e Henry Thomas Colebrooke.

A tópica da ruína produz um efeito de fruição e sedução estética que resulta de uma percepção da natureza como potência sobre a obra humana. Também Atenas, "a mãe das artes e eloquência", sucumbe em ruínas frente o domínio turco, faz notar Maria Graham na carta VI de Letters on India. Tal apreensão da paisagem indiana é perceptível nas descrições dos templos que ganha expressão através da retórica do pitoresco e do sublime. Segundo Simmel, toda ruína exerce um efeito trágico que, paradoxalmente, produz a sensação de paz. Essa mobilização de sentimentos tem origem no passado que toda ruína carrega. Uma nostalgia que, na tragicidade cômica, modula a elevação do espírito à fruição metafísico-estética. ${ }^{46} \mathrm{~A}$ ruína desloca para o presente um passado na forma que inclui a decadência.

Maria Graham descreve o antigo sistema de religião e a mitologia hindu pelos passos de Colebrook. ${ }^{47}$ Após longa exposição, aponta a similitude entre as divindades hindus e as de Grécia e Roma. Acrescenta na confirmação de seu argumento acerca do trânsito de civilizações, um relato sobre o comportamento dos regimentos sepoy enviados ao Egito em 1801, que se prostraram diante dos deuses do templo de Tentyra, reconhecidos como suas próprias divindades. ${ }^{48} \mathrm{~A}$ correspondência entre os diversos fluxos religiosos expressa uma mesma natureza que une o coração do homem ao autor da existência, numa alusão a Elements of the Philosophy of the Human Mind, de Dugald Stewart. Embora lembre o que a religiano carrega de superstição e barbárie, revela que não é indiferente ao seu sentido para os povos crentes:

Pela minha parte, vivendo entre o povo, e vendo diariamente o devoto prostrado, o templo, o altar, e a oferenda, eu tenho interesse neles, o que compensa a falta de beleza poética. Nem posso olhar com indiferença a um sistema, por mais bárbaro e supersticioso, que tão fortemente envolve as mentes dos seus adeptos, e que pode levá-los a desprezar a morte e a tortura nas suas formas mais terríveis. ${ }^{49}$

O também orientalista francês François Bernier (1625-1688) e seu livro sobre o império mongol, Voyage dans les Etats du Grand Mogol, compõem uma fonte de estudo para Maria Graham. Berrier é citado em Journal of a Residence in India no relato sobre a formalidade cerimoniosa de que a visita à casa de um "oriental" pode ser revestida e a ofensa em se recusar de um indiano a bebida que é oferecida. Bernier, adiciona Maria Graham, conta a história do jovem nobre que toma bebida, que já sabe envenenada, para provar sua lealdade ao anfitriāo. ${ }^{50}$

Como já sugerido, Maria Graham expõe os critérios que modelam uma metodologia da escrita. A narrativa é construída por meio da observação, da escuta de depoimentos e da leitura de textos escritos por informantes, escritores e estudiosos, reproduzidos por paráfrase. Faz alusão à importância das referências a especialistas que acrescentam informação erudita ao relato, como também confiabilidade. Um procedimento do método que combina arqueologia, etnografia, geografia e história na descrição marcada por uma pontuação modulada por uma estrutura de diário de observação. $\mathrm{O}$ ritmo coloquial da escrita faz com que os depoimentos e as referências a autores componham mais um tipo de organização de padrão erudito, de colecionador de artefatos letrados do que de um espírito científico. Assim, a curiosidade orienta uma perspectiva que revela o que permanece ainda da antiguidade oriental que dialoga com as matrizes ocidentais. É mais o passado que é interessante e não o presente. O presente é decadência. E esse é um traço da produção dos orientalistas sobre a Índia que justifica a ação civilizatória britânica. ${ }^{51}$

Em Letters, é mais clara a influência das teorias dos estágios de desenvolvimento da humanidade que se disseminaram no século XVIII. Predomina uma perspectiva do continuum entre as civilizações. 
A perspectiva da teoria dos estágios de civilização (nômades-caçadores, pastores, agricultores e comerciantes), presente no iluminismo escocês, atravessa a perspectiva de Graham sobre a Índia.

A teoria dos quatro estágios, de acordo com Poccock, indica a apreensão de uma abordagem historicizante sobre a natureza humana, em que se articulam natureza e controle das paixóes, a partir de um ordenamento sequencial histórico. ${ }^{52}$ Ele dá como exemplo Decline and Fall..., de Gibbon, na reflexão do capítulo 9, em que recorre à descrição de Tácito sobre os "alemães primitivos". A influência do iluminismo escocês foi disseminada pelos salōes frequentados por acadêmicos, cientistas, artistas, o grand monde em que o ritmo da conversa era pontuado pelo debate intelectual. O salão foi o espaço em que a civilidade se exercia na busca de conhecimento e em que conceitos e concepçóes ligadas ao ambiente das ilustrações européias se disseminaram.

Maria Graham, em suas memórias, comenta a leitura de Decline and Fall..., no período de sua estada em Richmond, por volta de 1806 e 1808, num exemplar da biblioteca de seu tio David Dundas, com quem partilhou conversas sobre o livro. ${ }^{53}$ Foi por intermédio de Gibbon que passou a ler Johann Lorenz von Mosheim (1693-1755) e descobriu o interesse pela história eclesiástica. Nesse período, assinala, também, a leitura da tradição romana de história em Políbio e Tácito. Lembra que estudou Antiquities do antiquário francês maurista Bernard Montfaucon (1655-1741). ${ }^{54}$ Essas leituras, que organizaram sua formação intelectual, indicam a relação com o ambiente do campo da história, do antiquarianismo e o espírito da época. Lembremos que, em sua autobiografia, Maria Graham menciona a proximidade com os segmentos letrados do iluminismo escocês, em Edinburgh, cidade de origem da família paterna, os Dundas, onde permaneceu longa temporada e frequentou os círculos letrados.

O padrão ainda predominante dos estudos antiquários era caracterizado pela coleção e o acúmulo de expertises. Antiquities, versão em inglês de L'Antiquité expliquée et representée en figures (1719-24), constitui-se em um catálogo de esculturas e figuras da arquitetura greco-romana que impõe modelos de monumentos, estabelecendo um traçado ao desenho que organiza o olhar do bloco arquitetônico. É essa a perspectiva que prevalece nos desenhos da arquitetura hindu em Letters on India, alguns de autoria da própria Maria Graham e do jovem amigo J. D. Glennie de Duwilch. ${ }^{55}$ As ilustraçôes mostram a separação de conjuntos em detalhes de estilos de colunas, capitéis, pilastras e de esculturas (Figura 1), como se Antiquities servisse de manual para a representação visual de construções que sempre remetem à antiguidade clássica.

A gruta de Carli é um dos espaços mais bonitos que já conheceu, revela Maria Graham, em Journal of a Residence in India. ${ }^{56} \mathrm{O}$ exercício comparativo do argumento constitui uma das estratégias discursivas de sua escrita. Desse modo, assinala que Carli, um templo jainista, não possui celas individuais de rituais secretos, como não há personalização da divindade, como nas grutas de Elephanta. A descrição remete para a experiência de êxtase, tanto pela proporção, quanto pelo que demonstra da maestria do trabalho humano. A gruta localizada no topo de montanhas, com rochas proeminentes, florações de perfume inebriante, descortina uma paisagem desconhecida ao viajante europeu, que o faz esquecer o risco de tigres e cobras na proximidade da floresta. A escrita de Maria Graham busca em imagens conhecidas descrever o novo cenário e expõe o encantamento com a incomensurabilidade da projeção da altura e do teto através do registro da catedral gótica. A narrativa prossegue com elementos que detalham, no estilo antiquário, os pilares e as colunas. A ilustração da parte central, com destaque das colunas enfileiradas, em que arcos e arcadas se elevam em direção ao céu (Figura 2), é impressa pelo gravador James Storer (17711853). O leitor é conduzido pelos corredores e às inúmeras salas da gruta que compõem as células, uma distribuição que lembra os monastérios do cristianismo. ${ }^{57}$ A descrição das características arquitetônicas combina-se ao relato sobre a religião do jainismo e à surpresa frente à magnificência do local.

Na proximidade da cidade de Toolsi, no raio de abrangência de Bombaim, Maria Graham visitou as grutas de Canary, também templo jainista. Em uma das cavernas do conjunto de Canary, destaca aspectos de semelhança com Carli, mas lamenta a sua transformação em igreja, realizada pelos portugueses, 
apagando as referências pagãs. Adota o instrumento da comparação ao descrever o pórtico de Canary, que embora não tão bonito como o de Carli, apresenta elegância; como também registra as estátuas de sete metros e meio de altura, na entrada de uma das cavernas, e a semelhança com a imagem de Buda que viu na passagem pelo Ceilão.

Maria Graham segue convenções da escrita de viagem que protegem e asseguram a autoridade do narrador pelo recurso a detalhes e medidas, divisões de monumentos e espaços, em que se cria uma visualização que transporta autor e leitor na mesma viagem imaginária, num tempo que imobiliza o passado no presente, como um instantâneo de fotografia.

$\mathrm{Na}$ descrição da natureza, concentra-se no conhecimento de naturalista de uma estudiosa de botânica, prática que cultivou desde a infância na escola de Drayton, no sul da Inglaterra, e que irrompe nos livros que publicou mais tarde, em que descreve a experiência epifânica na visão da vegetação tropical do Brasil. Na aridez subterrânea das grutas a euphobia oferece novo colorido à cena.

Deixando este grupo de cavernas, subimos o morro por um caminho rude, que conduz a passos talhados na rocha; e não se encontram poucas cavernas, como eu esperava, mas toda uma cidade escavada na montanha, que é perfeitamente exposta, mas cercada por morros arborizados. Algumas das cavernas são pequenas, e parecem adaptadas para residências particulares; em cada há um reservatório de água excelente, outras são grandes; e eu podia imaginá-las residência de sacerdotes ou pessoas de distinção. Uma em particular tem uma longa varanda na frente; o interior da câmara é de cerca de quarenta metros quadrados, seus lados são cobertos com figuras de santos Jine, quatro dos quais estão de pé, outros sentados em postura de meditação, ou de raciocínio, com o dedo indicador da mão direita no polegar da esquerda. Portas estreitas em três lados da caverna levam a células de dez metros por seis, em cada uma das quais há um assento levantado, o quarto lado tem uma porta e várias janelas olhando para a varanda. As pequenas cavernas estão em uma variedade de formas e os pilares que lhes dão suporte não são menos variados, acho que nenhum deles é feio, e muitos são muito elegantes. A grande caverna está em uma garganta, onde há arbustos e árvores; há pedras empilhadas que rolaram de outras cavernas, de modo a apoiar a terra, onde algumas poucas árvores florescem, e tornam o local mais frio do que qualquer outra parte desta cidade subterrânea, que com exceção daqui, não há vegetação, mas aqui e ali uma euphobia, que parece enraizar-se na própria pedra. ${ }^{58}$

A visita ao jardim botânico em Barrackpore, ${ }^{59}$ próximo a Calcutá, sessenta milhas, seguindo sempre a medição meticulosa de Graham, ocasiona uma pausa na narrativa frente ao encantamento com a magnificência dos exemplares que parecem conter a natureza do mundo numa estufa ficcional. A natureza medida, classificada e ordenada desperta maior fascínio. Grandes coleções de todo o mundo surpreendem pela diversidade: a figueira com a ramificação vigorosa de suas raízes e copa frondosa; a adannósia e seus troncos rugosos e robustos, "monstruosos". Calcutá, na região de Bengala, foi cidade símbolo da instalação do poder da East Indian Company, cuja marca permaneceu no grandioso palácio de governo, construído por Lord Wellesley em 1799, quando governador geral da Índia (1798-1805). A suntuosa construção mereceu uma ilustração de Graham, no Journal of a Residence in Índia (Figura 3). ${ }^{60}$

$\mathrm{Na}$ carta II, em Letters on Índia, Maria não aconselha a seu amigo epistolar imaginário, o aprendizado do sânscrito para uma breve permanência na Índia. A organização do campo orientalista nas últimas décadas do século XVIII atribui importância destacada às línguas orientais que, no caso da Índia dos britânicos, desdobra-se no investimento em estudos da literatura e língua sânscrita. A criação da cadeira de sânscrito no Collège de France foi estimulada pela disputa dos franceses com os britânicos e não por razões de interesse prático, da política, economia ou burocracia. A projeção do aprendizado dessa língua antiga, de letrados religiosos, na seara intelectual sobre o Oriente, organiza novos ramos de estudo, como os da gramática comparativa de uma matriz indo-europeia comum, e pesquisas sobre religião e filosofia da Índia antiga ${ }^{61}$ Ao discorrer sobre a temática do sânscrito, Journal e Letters recorrem às publicações de Colebrooke que deu continuidade aos estudos de William Jones e à tradução da lei hindu Vivadabhangarnava, de Jagannath Tarkapanchanan, para o inglês, Digest of Hindu Law on Contracts and Successions (1709). Colebrooke foi presidente, entre 1806 e 1815, da Asiatic Society of Ben- 
gala, fundada por William Jones, em 1784, com o apoio do controverso administrador da East India Company, Warren Hastings. ${ }^{62}$

O passado indiano e o que dele o presente reteve nos resquícios que o novo orientalismo traduz, insere-o no patamar civilizatório equivalente e até superior, já que anterior, ao do mundo grego na antiguidade. A mesma descoberta, manifesta na observação da paisagem construída da Índia, é repetida no estudo do sânscrito, que também indica a construção de uma mesma matriz indo-europeia.

$\mathrm{Na}$ exposição do tema das línguas, Maria Graham mantém o argumento de William Jones, repetido em Colebrooke, que vincula as línguas indo-europeias a um tronco comum que, sucessivamente, a partir da influência local do clima, originou o sânscrito na Índia, o pálavi na Pérsia e o grego na costa mediterrânea. Ela identifica quatro línguas na Índia: sânscrito, a língua dos deuses, da literatura, da ciência, da religião e da lei; o Pracrita, ou língua falada; Paisachi, ou língua dos demônios e Magad'hi, cujo uso não explicita. ${ }^{63}$ Journal destaca a publicação, em 1808, de três gramáticas de sânscrito em inglês: a do Saraswata, por Colebrooke; a de Carey, que é parte tradução de gramáticas usadas em Bengala, adaptaçôes de professores que, lamenta Maria Graham, acomodaram a língua sagrada ao idioma e pronúncia vernáculos; e uma terceira, Sanscrit Grammar, de Wilkins. ${ }^{64}$ Lembra o comentário sobre um artigo da Edinburgh Review, que faz uma analogia entre o sânscrito e outras línguas e, na esteira de William Jones e Colebrooke, reproduz uma grade de vocábulos que possuem uma raiz comum. Lista palavras em sânscrito com equivalentes em latim, persa, alemão e inglês respectivamente: pitara, pater, pider, vater, father; matara, mater, mader, muder, mother; bhratara, frater, brader, bruder, brother ${ }^{65}$ A percepção da variedade de dialetos na Índia e as analogias que faz entre as línguas remetem o leitor à familiaridade de Maria Graham com o campo do orientalismo. A repercussão dos estudos sobre a Índia, em Journal of a Residence in India e Letters on Índia, mostra, por um lado, a maciça e volumosa produção de conhecimento sobre o Oriente em língua inglesa, sob os auspícios da East India Company e, por outro, sua disseminação, entre os segmentos letrados e setores médios, de práticas de leitura e estudo que passavam a constituir valores positivos de civilidade. Expõe, também, o processo de trabalho e organização da escrita de Maria Graham que prioriza o levantamento de informações, de fontes, de obras de especialistas, seja sobre história, geografia e as línguas dos lugares visitados. Na marcação de Journal of a Residence in India, em 12 de março, a bordo do H. C. Cruiser Príncipe de Wales, na costa de Malabar, no retorno do Ceilão para Bombaim, descreve uma rotina em que sobressai o tempo do estudo e de leitura coletiva. Após o café da manhã às nove horas, na monotonia de bordo, um integrante do grupo lê em voz alta, e, em seguida, Maria Graham estuda por duas horas e meia, para novamente juntar-se aos companheiros no jogo de whist ou gamão. ${ }^{66}$

Segundo Edward Said, uma forma específica de saber sobre o Oriente, o "orientalismo", foi um instrumento de consolidação da dominação britânica na Índia. Chistopher A. Bayly, em crítica à perspectiva de Said, que congela as relações de dominação, aponta para a complexidade das redes de poder, ao analisar o dinamismo dos mecanismos de comunicação e informação, na Índia pré-colonial, e as formas de apropriação, pela Companhia das Índias Orientais, dos meios de comunicação e circulação da informação. Também indica a apropriação, pelas elites indianas, das formas de saber ocidental e seu uso no enfrentamento do poder britânico. ${ }^{67}$ Deste modo, vislumbra-se um quadro complexo dos encontros culturais e das formas de dominação, circulação e apropriação da informação e do conhecimento pelos nativos. ${ }^{68}$

É a partir da disseminação da teoria dos estágios que a escrita grahamiana entende a Índia como precursora do mundo ocidental, uma cultura mais antiga que a grega. Essa perspectiva justifica não apenas a dominação britânica, mas engrandece a sua missão civilizatória. ${ }^{69}$ A escrita do Journal of a Residence in India e de Letters on India naturaliza a Índia como inglesa. A adesão a uma visão centrada na superioridade cultural britânica organiza a compreensão da alteridade e das estruturas de gênero, favorecendo uma compreensão dos homens e das mulheres de culturas alienígenas como inferiores. ${ }^{70}$ Logo no início da estada na Índia, no primeiro contato com a sociedade inglesa de Bombaim, Maria Graham 
é irônica com relação às mulheres de origem britânica que habitam o espaço indiano; elas despontam da narrativa, através de imagens associadas à submissão aos últimos modelos europeus que chegavam pelo paquete. Já em Calcutá, após meses de permanência na Índia, encanta-se com a vida intelectual da sociedade inglesa, que aviva a lembrança do país de origem, onde, comenta, o pensamento floresce como em nenhum outro. Refinamento é o termo usado para qualificar a superioridade inglesa, e por associação, europeia; já os depreciativos "apático" e "degradante" são empregados para comentar o mundo "supersticioso" dos habitantes da Índia. ${ }^{71}$

Os dois livros de Maria Graham sucedem publicações sobre a Índia escritas por mulheres, Letter from a Lady in Madras to Her Friends in London (1743), de Jane Smart, e Letters from Teneriffe, Brazil, the cape of Good Hope, and the east Indies (1777), de Jemina Kindersley (1741-1809). ${ }^{72}$ Nesse sentido, na escrita de Maria Graham ressoam elementos da fabricação do Império britânico e sua expansão nas primeiras décadas do século XIX, quando se observa o crescimento da consciência nacional e do papel de mulheres dos setores médios na defesa de ideais patrióticos. A partir de meados de 1770, as representaçôes de mulheres do Oriente são usadas no estabelecimento da diferença e da superioridade da mulher branca britânica. ${ }^{73}$ A coloração feminista em Letters on Education (1790), de Catherine Macaulay, e Vindication of the Rights of Woman (1791), de Mary Wollstonecraft, produz as imagens do harém como símbolo da opressão da mulher. ${ }^{74}$ Montesquieu, em Cartas Persas (1721), já comparara a reclusão da mulher no Oriente, em contraste com a liberdade feminina de movimento no Ocidente. Este constitui mais um dos topoi que se repetem acerca das mulheres orientais. O contrapeso da mulher confinada na domesticidade é a mulher ativa nas atividades de religião e filantropia. ${ }^{75}$ Ao final do século XVIII, cresce a difusão das sociedades missionárias de denominações protestantes e a fixação da mulher britânica dos setores médios nas atividades de filantropia, ${ }^{76}$ as exploradoras sociais, na expressão de Mary Pratt. ${ }^{77}$

A percepção da mulher refém do espaço da casa atravessa também a escrita de Maria Graham, acerca das brasileiras e portuguesas, em seu Diário sobre o Brasil. A viagem à América do Sul, 12 anos após a partida da Índia, introduziu a percepção acerca dos portugueses em outra chave de leitura que o livro sobre a Índia não contemplou. Portugal é uma omissão nos livros sobre a Índia, escritos por Maria Graham que percorreu locais na costa de Malabar que tangenciavam cidades integradas aos domínios portugueses. O fulgurante império asiático português do Quinhentos, já no início do século XIX, remetia a um tempo pretérito do esquecimento, que obliterava a primeira chegada de europeus aos mares do Índico, "onde não se atreveu passar Trajano", como a épica dos versos camonianos dos Lusíadas no canto VI imortalizou.

Segundo Sanjay Subrahmanyan, até 1700, na Índia portuguesa - Goa, Baçaim e Diu -, o sistema de governança do Império português manteve-se. Em outras áreas da Ásia, os descendentes de portugueses preservavam a identidade e nutriam a expectativa de reconstrução do antigo Estado da Índia. ${ }^{78}$

No início do século XIX, o termo "português", na narrativa grahamiana, resvala para uma conotação negativa, com o emprego de adjetivos depreciativos. Em Journal of a Residence in India, os portugueses, quando presentes na narrativa, aparecem em sentido negativo, sujos; e as igrejas, registros da presença cristã no Oriente, oferecem o aspecto de abandono. ${ }^{79}$ Logo após a chegada a Bombaim, Graham descreve a sujeira da cidade cristã portuguesa de Mazagong, e comenta, em associação a essa percepção, a grande quantidade de porcos que perambulavam pela cidade. ${ }^{80}$ Ao comentar sobre um jantar no período inicial em Bombaim, destaca novamente a aparência de sujeira dos portugueses. $\mathrm{O}$ adjetivo "sujo" desliza na expressão "homens pretos", com hábitos percebidos como estranhos: comem porco, vestem culotes. A frase avança e acrescenta a esse cenário sombrio o convívio no trabalho com "párias", ainda mais sujos. ${ }^{81}$ Os sinais que remetem aos portugueses no território indiano mostram um quadro de decadência. Como assinalamos acima sobre o templo de Carli, também na visita ao templo de Elephanta, Journal comenta que a guerra dos portugueses aos deuses e templos, somada à ação do tempo, reduziu o grande monumento da idolatria a um estado de decadência. 
Maria Graham lamenta que vislumbrou a Goa portuguesa, mas que não teve como saciar sua curiosidade. O movimento dos ventos impediu que a embarcação atracasse no cais da cidade portuguesa e, assim, que ela visitasse as exuberantes igrejas de mármore e os belos monastérios. Na repetição do interesse pelos lugares que assinalam as marcas do roteiro do viajante oitocentista, Maria Graham indica a intenção de render homenagem ao túmulo de São Francisco Xavier, o "apóstolo do Oriente". A decepção avivou a lembrança do quadro de miséria da antiga colônia, com seu passado de esplendor, e suscitou um comentário acerca das mulheres de "boas famílias" que bordam e fabricam flores artificiais para a sobrevivência. ${ }^{82}$

A política externa no quadro europeu dos séculos XVII e XVIII aproximou Portugal e Inglaterra, com repercussão na região indiana, simbolizada pela inclusão de Bombaim no dote de casamento da infanta Dona Catarina de Bragança com Carlos II, em 1661. À época da estada de Maria Graham no subcontinente indiano da East India Company, os resíduos do velho Império fragmentavam-se e, ao olhar europeu, a antiga pujança do comércio português no espaço asiático caíra numa zona de esquecimento. A Goa Dourada, com a paisagem branca de sua geografia religiosa, inscrita no universo regido pela concepção teológico-política da monarquia portuguesa da contrarreforma ibérica, ainda formava um registro mnemônico que atribuía um sentido histórico a Portugal na Índia, através do santo símbolo da civilização ocidental no espaço asiático que é São Francisco Xavier. Da Goa perdida nas sombras do passado, sobrepóe-se Calcutá como a nova cidade, símbolo da civilização ocidental no Oriente.

Maria Graham embarcou em Madras na fragata HMS Barbados, em 21 de fevereiro de 1811, com destino à Inglaterra, após uma permanência de quase dois anos. Na narrativa de Journal of a Residence in India - que traz ainda registros da passagem pela cidade do Cabo, recente possessão inglesa e antigo domínio neerlandês, no sul da África -, 27 de junho é a última data assinalada. Antes da visão de Portsmouth, Maria Graham antecipa a sensação epifânica prometida pela visão do desenho das montanhas, do calidoscópio de cores do campo inglês, das torres e pináculos das cidades, descrição de uma paisagem familiar que compensaria os perigos e as dificuldades que enfrentou, desde a partida de casa, encerrando, assim, o Journal of a Residence in India. ${ }^{83}$

\section{Notas}

${ }^{1}$ Ralph Dundas era surdo-mudo e estudou, segundo informação de Maria Graham em suas memórias publicadas postumamente, em Braidwood's Deaf and Dumbs Academy. Cf. GOTCH, Rosamund Brunel. Maria Lady Callcott. The creator of "LittleArthur". London: John Murray, 1937, p. 71.

${ }^{2}$ Em seu diário pessoal, Maria Graham menciona que chegou numa quinta-feira, por volta de três horas da tarde, em 25 de maio, um dia antes do que é registrado em Journal of a Residence in India. Idem, p. 135.

${ }^{3}$ Cf. BAILY, Christopher. The Birth of the modern World: 1780-1914. Global Connections and Comparison. Oxford: Blackwell, 2004, p. 125.

${ }^{4}$ Cf. SCHAMA, Simon. A History of Britain 2 1603-1776. The British wars. Londres: BBC Books, 2001, p. 386.

${ }^{5}$ A expressão "momento maquiavélico" refere-se ao impacto da secularização no âmbito da ideia de República e o confronto entre "virtude", "fortuna" e a "corrupção". Na perspectiva do embate político do Setecentos na Grã- Bretanha, trata-se de enfocar a continuidade histórica do "momento maquiavélico", no sentido dos problemas colocados por uma dimensão do tempo secular e o desdobramento do humanismo cívico no confronto entre virtu e corrupção, em que o vocabulário humanista e maquiaveliano é mostrado como veículo de uma percepção basicamente hostil ao primeiro capitalismo inglês. A atuação de Edmund Burke na crítica a Warren Hastings (1732-1818), primeiro governador geral da Índia britânica, é a fase derradeira desse prolongamento de questôes que dizem respeito a conceitos e valores republicanos e maquiavelianos, tanto quanto os constitucionalistas na Inglaterra. Ver POCCOCK, J. G. A. The Maquiavellian Moment. Florentine Political Thought and the Atlantic Republic Tradition. New Jersey: Princeton University Press, 1975.

${ }^{6}$ A violência e a rapacidade da companhia são acentuadas por Edmund Burke: "Our conquest there, (...), is as crude as it was the first day. (...) Animated with all the avarice of age and all the impetuosity of youth they roll in one after another, wave after wave; and there is nothing before the eyes of the natives but an endless, hopeless prospect of new flights of birds of prey and passage, with appetites continually renewing for a food that is continually wasting. Every rupee of profit made by an Englishman is lost forever to India." Citado em SCHAMA, Simon, op. cit., p. 389. 
${ }^{7}$ Cf. MARSHALL, P. J. The Bristish in Asia: Trade to Domination, 1700-1765. In MARSHALL, P. J. (ed.) The Oxford History of the British Empire, v. II. The Eighteenth Century. Oxford: Oxford University Press, 1998, p. 487.

${ }^{8}$ Bayly afirma que no período anterior a 1760, o acúmulo de conhecimento e informação acerca da região indiana pelos britânicos era inferior ao dos holandeses, que tiveram acesso aos registros dos mongóis. Desse modo, tinham controle de dados sobre a navegação entre Europa e Ásia nos portos indianos. "Even so, before the 1762 British commercial knowledge was never as full as that of the Dutch who had gained access to Mungal customs records and were consequently able to keep track of all European and Asian shipping in Indian ports. The British achieve this until after they gained direct control of Indian territory, which time indigenous shipping had lost much of its importance.” BAYLY, Christopher A. Empire and Information. Intelligence Gathering and Social Communication in India, 1780-1870. Cambridge: Cambridge University Press, 1996, [Cambridge Studies in Indian History and Society], p. 45-46.

${ }^{9}$ Cf. MARSHALL, P. J. The First British Empire. In WINKS, Robin (ed.). The Oxford History of the British Empire. Volume V. Historiography. Oxford: Oxford University Press, 1998.

${ }^{10}$ Cf. STAFFORD, Barbara Maria Voyage into Substance: Art, Science, Nature and the Illustrated Travel Account, $1760-1840$. Cambridge: Cambridge Mass, MIT Press, 1984.

${ }^{11}$ Habermas assinala a distinção entre o termo opinião equivalente a "mero palpite", uma acepção, portanto, negativa, e julgamento, verdade, razão, a capacidade de avaliação e controle do Estado. A emergência do que equivale à opinião pública é projetada no exemplo da ação da denúncia de corrupção a Warren Hastings por Edmund Burke na Inglaterra ao final do século XVIII. Cf. HABERMAS, Jürgen. Mudança estrutural da esfera pública. Rio de Janeiro, Tempo Brasileiro, 2003 , p. 110.

12 "In classical terms, however, the true awkwardness of 'opinion' as a directing force in society lies in the rootedness of opinion not merely in the private person, but in the private mind. Whatever its ultimate expression, 'opinion' is shaped by individual subjectivity and inter-subjective exchange-the same inward aspect of private life in which Smith investigated the training of our 'moral sentiments'.” PHILLIPS, Mark Salber. Reconsiderations on History and Antiquarianism: Arnaldo Momigliano and the Historiography of Eighteenth-Century Britain. Journal of the History of Ideas, v. 57, n. 2 (Apr., 1996), p. 306.

${ }^{13}$ Segundo Michel Foucault, na "relação da linguagem com sua infinita repetição uma mudança se produziu no fim do século XVIII - quase coincidindo com o momento em que a obra de linguagem se tornou o que ela é agora para nós, ou seja, literatura." FOUCAULT, Michel Ditos e Escritos III Estética: literatura e pintura, música e cinema. Rio de Janeiro: Editora Forense Universitária, 2001, p. 53.

${ }^{14}$ Segundo Philippe Lejeune, o nome do autor-narrador-protagonista fundamenta o pacto autobiográfico que fornece legitimidade à autobiografia. Essa definição pode ser utilizada para o repertório de livros de viagem em que a narrativa se organizava pelo eu-autoral. Cf. LEJEUNE, Philippe. L'autobiographie em France. Paris: Armand Colin, 1971; Le moi des demoiselles. Enquête sur le journal de jeune fille. Paris: Éditions du Seuil, 1993.

${ }^{15}$ Chen Tzoref-Ashkenazi indica a centralidade do conceito de experiência no relato de viagem e analisa a polêmica entre Kant e o escritor de livro de viagens George Forster (1754-1794), que participou da segunda viagem de volta ao mundo de James Cook em 1772-75. Forster é o exemplo de autor que valoriza a experiência pessoal do viajante. Destaca que a observação empírica e a sistematização do conhecimento não devem ser separadas, uma resposta à crítica de Kant à literatura de viagem no ensaio "Bestimmung des Begriffs einer Menschenrasse" [Determinação do conceito de raça humana]. Cf. TZOREF-ASHKENAZI, Chen. The Experienced Traveller as a Professional Author: Friedrich Ludwig Langstedt, Georg Forster and Colonialism Discourse in Eighteenth-Century Germany. History. Vol. 95 Issue 317, p. 2-24. Disponível em <http:// www3.interscience.wiley.com/journal/123215515/abstract> Acesso em 02/02/2010.

${ }^{16}$ GOTCH, Rosamund Brunel, op. cit., p. 59.

${ }^{17}$ As obras dos portugueses João de Barros, Diogo do Couto e Antonio Bocarro, nos séculos XVI e XVII, constituem uma fase anterior de práticas de escrita que se inscrevem no esquadro do "orientalismo", como indicado por Charles Boxer (Apud CURTO, Diogo Ramada. “Orientalistas e cronistas do Quinhentos”. In Cultura Escrita. Séculos XV a XVIII. Lisboa: ICS, 2007). A nova fase dos estudos orientalistas possui os marcos fundantes das contribuições do erudito francês Anquetil-Duperron (1731-1805) e de William Jones, que desvelaram, segundo Said, a opulência do védico, do sânscrito. SAID, Edward. Orientalismo: o Oriente como invenção do Ocidente São Paulo, Companhia das Letras, 2003, p. 61.

${ }^{18}$ Ver sobre a descoberta do hinduísmo pelas academias britânicas KOPF, David. British Orientalism and the Bengal Renaissance: the dynamics of Indian modernizaiton 1773-1835. Calcutá: Firma K. L. Mukhopadhyay, 1969; MARSHALL, P. J. (ed.) The British discovery of Hinduism in the eighteenth century. Cambridge: Cambridge University Press, 1970 e CLARKE, J. J. Oriental Enlightenment: the encounter between Asian and Western thought. Londres: Nova Iorque, Routledge, 1997.

${ }_{19}$ William Jones, no primeiro discurso como presidente do jornal Asian Researches, em 1784, afirma que "Asiatick" é um termo mais clássico e apropriado do que oriental para a região que se estendia pelo norte da África, Turquia e Japão. Cf. TRAVERS, Robert. Ideology and Empire in Eighteenth-Century. The British Bengal. Cambridge Studies in Indian History and Society series. Cambridge: Cambridge University Press, 2007, p. 5, nota 17. Cf. <http://asiaticsocietycal.com/ history/1.htm> Acesso em 04/08/2010. 
${ }^{20}$ A publicação concentra debates e temas de interesse da Asiatic Society e do College em Fort William. Na conexão entre poder e conhecimento, a East Indian Company destaca-se pela participação no fomento e produção de conhecimento sobre a Ásia. Warren Hastings foi o primeiro presidente da Asiatic Society of Bengal e William Jones seu vice-presidente. Disponível em <http://asiaticsocietycal.com/history/1.htm> Acesso em 20/03/2010). Entre 1788 e 1839, quando foi substituída pelo Journal of the Asiatic Society, editou 20 volumes.

${ }^{21}$ A fixação do campo do orientalismo em Calcutá por Hastings incluiu o subcontinente indiano na produção intelectual da história, civil e militar, dos estudos antiquários, das artes, ciências e da literatura da Ásia. Ver ALMEIDA, Hermione de, GILPIN George H. Indian Renaissance: British romantic art and the prospect of India. Burlington, Ashgate, 2007, p, 58.

${ }^{22}$ A publicação com ilustrações fugia ao padrão mais popular dos pequenos exemplares in-12 ou in-16. Seu custo foi considerado elevado, segundo o comentário do Quartely Review em 1812: "Miss Graham will readily perceive, by the attention which we have given to her labours, that she has published her book in a form which must necessarily exclude it form general readers - but this is the vice of a luxurious age, which in time will correct itself." Sept-Dec., The Quarterly Review, v. VIII, p. 421. O periódico literário Quarterly Review foi fundado, em 1809, pelo célebre editor escocês John Murray (1778-1843), uma versão tory do whig Edinburg Review, de 1802. Ambas constituíam veículos de divulgação editorial e também dominaram esse universo de periódicos até 1810, quando novas revistas como a Blackwood's Edinburgh Magazine (1817) e a London Magazine (1820) confirmavam o crescimento do mercado de escritores, casas de edição e de leitores e são indicadores da ampliação da esfera pública na acepção habermasiana . Ver SCHOENFIELD, Mark. Novel Marriages, Romantic Labor and the Quartely Press. In WHEATLEY, Kim. Romantic periodicals and print culture. Londres, Routledge, 2003.

${ }^{23}$ Journal d' un séjour fait aux Indes Orientales pendant les années 1809, 1810 et 1811. Genebra/Paris: J.-J. Paschoud/ Maison de Commerce, 1818, é uma edição de 302 páginas e não reproduziu as ilustrações dos originais em inglês. A tradução adotou o formato epistolar, uma adaptação de Journal of a Residence in India, em 30 cartas.

${ }^{24}$ Cf. SCHOENFIELD Mark, idem, p. 77.

${ }^{25}$ Ver ARENDT, Hannah. A condição humana. 11르 Edição. Rio de Janeiro, Editora Forense, 2010, p.14.

26 "La historia del arte de la Antigüedad que me propongo escribir aquí no es uma mera narración de la serie temporal y de los cambios que tuvieron lugar em la misma, seno que tomo la palavra historia [Geschichte] em el sentido amplio que tiene em la lengua griega, y es mi intención producir um ensayo de um sistema doctrinal [Lehrgebaüde]". Apud KOSELLECK. Reinhart. historia/Historia. Madri, Editorial Trotta, 2004, p. 42.

${ }^{27}$ PHILLIPS, Mark Salber, op. cit., p. 307. Entretanto, Phillips menciona que Momigliano privilegia a vertente da pesquisa antiquária e não discorre sobre a histórica narrativa no século XVIII. A exceção acrescenta em nota de pé de página, é a rápida menção à filosofia da história e mesmo assim, destaca Phillips, não explora a relação com a tradição da história política (p. 303).

28 "Smith's hostility to innovations in historical narrative put him at odds with the most innovative developments in contemporary practice, including the work of his good friend David Hume. Yet it was precisely because Smith would not abandon history's commitment to classically prescribed forms of narrative that he produced a fertile reexamination of the way in which a narrative of private life might be constructed.” PHILLIPS, Mark Salber. Adam Smith and the history of private life: Social and sentimental narratives in eighteenth-century historiography. KELLEY, Donald R. e SACKS, David Harris (eds.).The Historical Imagination in Early Modern Britain: History, Rhetoric, and Fiction, 1500-1800. Cambridge: Woodrow Cambridge University Press, 2002. p. 320.

${ }^{29}$ Sobre as condições históricas da emergência da noção de sinceridade e as transformações morais de concepções sobre o sujeito ver TRILING, Lionel. Sincerity and Authenticity. Harvard: Harvard University Press, 1972.

${ }^{30}$ No sentido de formação individual e autorrealização da tradição alemã da Bildung. "The origin and nature of Bildung was a discipline of the self that was central to the struggle of nonnoble groups for a sense of self-worth, inner strength, and fulfillment in response to personal domination in the absolutist state and by the ideals of the nobility." GOLDMAN, Havey. Politics, death, and the devil: self and power in Max Weber and Thomas Mann. California: University of California Press, 1992. p. 26. Se a acepção de Bildung corresponde ao universo de língua alemã, porém um sentido da educação, como elemento de construção e formação do indivíduo, adquire um valor universal.

31 "Presidency" corresponde à divisão administrativa do território sob controle da East India Company. Bombaim e Madras completam o quadro das presidências.

${ }^{32}$ GRAHAM, Maria. Journal of a Residence in India. Segunda Edição. Edinburgh: George Ramsay and Company, 1813, p. VIII.

${ }^{33}$ Cf. LEASK, Nigel, Curiosity and the Aesthetics of travel writing 1770-1840. Oxford, Oxford University Press, 2002 , p. 207. Ver também Maria Graham. Journal of a Residence in India. Op. cit., p. 15.

34 "The Journal of a Residence in India, by a young lady who, probably, went thither, like most young ladies, to procure a husband instead of information, is a literary curiosity which we are not disposed to overlook." Quarterly review, v. 8 n. 16 (December 1812), p. 406. 
${ }^{35}$ A representação negativa de livros escritos por mulheres é constante no Quartely Review, como afirma Mark Schoenfield em estudo sobre a resenha do livro de Anna Letitia Barbauld, Eighteen Hundred and Eleven, no número anterior da Quartely Review: "Noticing Anna in the issue just prior to the review of Graham, the Quartely Review exclaims: 'We had hoped, indeed, that the empire might have been saved without the intervention of a lady-author' (Novel Marriages, Romantic Labor and the Quartely Press. In WHEATLEY, Kim. Romantic periodicals and print culture. Londres: Frank Cass, 2003. p. 78).

${ }^{36}$ Informação na página do Quarterly Review Archive. Disponível em <http://www.rc.umd.edu/reference/qr/index/61. html> Acesso em 05/02/1010. John Barrow, oficial da marinha, foi comentador assíduo do Quarterly Review, além de escritor de vários livros de viagem e membro da Royal Geographical Society, fundada em 1830.

${ }^{37}$ The British Review and London Critical, v. IV, p. 349-360.

${ }^{38}$ Cf. Monthly Magazine, v. 34, 1812, p. 632.

${ }^{39}$ Cf. LEASK, Nigel, op. cit., p. 206.

${ }^{40} \mathrm{O}$ Dictionary of the English Language, de Samuel Johnson, na 6a edição de 1785 e na $11^{\mathrm{a}} \mathrm{em} 1799$, indica dois sentidos para o vocábulo Journal, a mesma palavra, em francês, e giornale, em italiano (JOHNSON, Samuel. Dictionary of the English Language. Londres: J. F. and C. Rivington, L. Davis, T. Payne and Son... M. Newburt, 1785). Uma primeira acepção de diário, no sentido lato, de anotação dos negócios do dia, que se refere ao manejo administrativo ou de finanças. Uma segunda, do jornal publicado diariamente. A palavra journal, nas publicaçōes de Maria Graham, projeta já uma fusão desses dois sentidos. Uma modalidade de registro que articula a escrita de notação pessoal à prática da atividade do periodista, do recurso da imprensa diária na figura do jornalista. O crescimento do mercado da imprensa periódica reorganiza os protocolos de escrita que passavam a informar o livro de viagens e vice-versa. Lembremos a expansão da edição de jornais no século XVIII, na qual o sucesso de Spectator na Inglaterra é um exemplo. Cf. PALLARES-BURKE, Maria Lúcia Garcia. The Spectator. O teatro das luzes. Diálogo e Imprensa no século XVIII. São Paulo, Hucitec, 1995.

${ }^{41}$ Nas primeiras páginas, Journal of a Residence in India faz referência à biblioteca da casa de James Mackintosh (1764-1832), em Tarala, próximo a Bombaim, a melhor depois do Cape: "It is arranged in a large room like the cell of a temple, surrounded with a viranda inclosed by Venetian shutters, which admit and exclude the light anda ir at pleasure." GRAHAM, Maria. Journal of a Residence in India, op. cit., p. 6. Mackintosh, jornalista e jurista, foi, entre 1806 e 1813, juiz da corte do vice-almirantado em Bombaim. Cf. GOTCH, Rosamund Brunel, op. cit. 135.

${ }^{42}$ GRAHAM, Maria . Journal of a Residence in India, op. cit., p. 62. Essa passagem é também indicada por LEASK, Nigel. op. cit., p. 210.

${ }^{43}$ Idem, p. 144.

${ }^{44}$ No original: "There is something in the scenery of this place that reminds me of the beauty of the banks of the Thames: the same verdure, the same rich foilage, the same majestic body of the water." GRAHAM, Maria. Idem, p. 144.

${ }^{45}$ Autores de romances de ficção identificados ao estilo gótico como Ann Radcliffe (1764-1823), em The Castles of Athlin and Dunbayne. A Highland Story (1789), Matthew Lewis (1775-1818), com The Monk (1796), Mary Shelley (1797-1851), com Frankenstein (1818), e Charles Maturin (1782-1824), autor de Melmoth the Wanderer (1820), configuraram maneiras de olhar a natureza e formas de construção da paisagem influenciadas pelas ideias do belo e sublime de Edmund Burke (1729-1797) e do pitoresco de William Gilpin (1724-1804). Segundo a indicação de Maria Graham no seu relato autobiográfico, a leitura de Burke foi indicada pelo seu professor de desenho, William Delamotte (1775-1863), filho de um refugiado francês da Revolução que estudou com Benjamin West (1738-1820), pintor que presidiu a prestigiosa Royal Academy de Londres, fundada em 1768, durante o reinado de George III (Cf. GOTCH, Rosamund Brunel, op. cit., p. 44). Segundo Nigel Leask, o efeito do pitoresco é a curiosidade; menos esplêndido do que o sublime, produz uma influência mais geral, "corrige o langor da beleza ou o horror do sublime" (LEASK, Nigel, op.cit. p. 173).

${ }^{46}$ SIMMEL, Georg. The ruin. In Kurt Wolff. Georg Simmel: 1858-1928 (A collection of essays). Ohio: Ohio State University Press, 1959.

${ }^{47}$ Colebrook indica cinco seitas (sects): saivás, adoradores de Siva ou Maha Deo; Vaisnavas, adoradores de Vishnu; os Sauras, Surya ou o sol; Ganepatyas ou Gosseinas, Gundputti ou Ganesa; e os Sactis, bawanee ou Parvati. Cf. GRAHAM, Maria. Journal of a Residence in India, op. cit., p. 45.

${ }^{48}$ Idem, p. 52.

${ }^{49}$ No original: "For my own part, living among the people, and daily beholding the prostrate worshipper, the temple, the altar, and the offering, I take an interest in them which makes up for their want of poetical beauty. Nor can I look with indifference upon a system, however barbarous and superstitious, which has so strong a hold of the minds of its votaries, and which can bring them to despise death and torture in their most dreadful forms." Idem, p. 52.

${ }^{50}$ Ibidem, p. 19. A menção a Bernier, Jones e Colebrooke no segundo livro, Letters on India, mostra que o formato epistolar forjou um modelo mais ensaístico, em que o estudo e a erudição, na tradição antiquaria e da escrita orientalista se adequam a um padrão de narrativa distinto do que adota em Journal of a Residence in India. 
${ }^{51}$ Adam Smith elaborou a teoria dos quatro estágios na Escócia, na mesma época que Turgot na França, e consta no Wealth of Nations. A elite intelectual escocesa, de uma maneira ou de outra, concebeu ou partilhou da tese dos estágios na compreensão do desenvolvimento da civilização. Entre eles, o filosofo e historiador David Hume, Francis Hutcheson, o jurista Henry Home, Lord Kames, o chefe da Igreja da Escócia e da Universidade de Edinburgh William Robertson, Adam Ferguson, Thomas Reid e John Millar. A teoria dos estágios incorpora uma concepção da história como processo que evolui da barbárie ao patamar civilizatório, uma perspectiva econômica em que o progresso impulsiona a expansão por meio do comércio da sociedade. Contudo, os letrados escoceses, à exceção de Ferguson, não partilham de um horizonte de expectativas de otimismo por um progresso indefinido. Está presente a preocupação moral com um futuro em que a opulência e a riqueza ameaçam e desestabilizam a sociedade. Cf. SPADAFORA, David. Progress. In KORS, Alan Charles (ed.). Encyclopedia of the Enlightenment, v. 3. Oxford: Oxford University Press, 2003, p. 367. A concepção de história afastava-se da matriz da exemplaridade clássica e incorporava a dimensão de regularidade da natureza humana, na qual o aprimoramento social indicava também um aprimoramento do indivíduo.

${ }^{52}$ Cf. POCCOCK J. G. A. A mobilidade da propriedade e o nascimento da sociologia do século XVIII. Linguagens do Ideário Político. São Paulo, Edusp, 2003, p.156.

${ }^{53}$ GOTCH, Rosamund Brunel, op. cit., p. 87.

${ }^{54}$ Frade beneditino, da Congregação de Saint-Maur, Montfaucon foi membro da Académie des Inscriptions et Belles-Lettres e fundou a Academie des Bernardins. Cf. SOLL, Jacob. Jean-Baptiste Colbert's Republic of Letters. Republics of Letters: A Journal for the Study of Knowledge, Politics, and the Arts 1, no. 1 (May 1, 2009). Disponível em <http://rofl.stanford.edu/ node/28> Acesso em 20/08/2010.

55 GRAHAM, Maria, Letters on India, op. cit., p. 381.

${ }^{56}$ GRAHAM, Maria. Journal of a Residence in India, p. 64.

${ }^{57}$ James Storer, por sua vez, é um desenhista especializado em retratar igrejas e catedrais medievais. A ilustração de Maria Graham da gruta de Carli, como uma projeção de uma catedral gótica, através do jogo de escala dos arcos, oferece ao leitor de Journal of a Residence in India a confirmação do que é já familiar ao europeu, como destaca a narrativa. James Storer denomina esse gênero de arquitetura de "antigo". Ver STORER, James; GREIG, John. Antiquarian and Topographical Cabinet, containing a series of elegant views of the most interesting objectis of curiosity in Great Britain. Vol 1. Londres, Clarke, Carpenter, Chapple, Ricahrdson, Sherwood, Neely e Jones, 1807. Sobre os dados biográficos de James Storer consultar <http://www.antiquemapsandprints.com/traveller.htm> Acesso em 20/02/2010. Todas as ilustrações do Journal são de Graham, com gravação de Storer.

${ }^{58}$ No original: "Leaving this group of caves, we ascended the hill by a rude path, which leads to steps cut in the rock; and found not a few cave, as I expected, but a whole city excavated in the mountain, which is perfectly bare, but surrounded by woody hills. Some of the caves are small, and seem adapted for private dwellings; to each of these there is a reservoir of excellent water; others are large, and I could imagine them the residence of priests or persons of distinction. One in particular has a long viranda in front; the chamber within is about forty feet square, its sides are covered with figures of Jine saints, four of which are standing, the others sitting in the posture of meditation, or reasoning, with the fore-finger of the right hand applied to the thumb of the left. Narrow door-ways in three sides of the cave lead to cells of ten feet by six, in each of which there is a raised seat; the fourth side has one door, and several windows looking into the viranda. The small caves are in a variety of shapes and the pillars that support them are not less various; yet I think none of them are ugly, and many are very elegant. The large square cave is in a ravine, where there are shrubs and trees; over it the stones dug from other caves are piled, so as to support earth, where a few trees flourish, and render the spot cooler than any other part of this subterraneous city, for excepting here, there is no vegetation but now and then an euphorbia, which seems to root in the stone itself." GRAHAM, Maria. Journal of a Residence in India, op. cit., p. 117. Grifos meus.

${ }^{59} \mathrm{O}$ jardim botânico teve início com Robert Kyd em 1787, um local de aclimatação de plantas, especiarias, da árvore teca, típica da Índia. O botânico William Roxburgh assumiu a direção seis anos após sua fundação e o projetou como um jardim botânico com plantas da Índia e asiáticas em geral. Introduziu a mahogany com sementes das Índias ocidentais inglesas. Na época da passagem de Maria Graham por Calcutá, permanecia ainda no cargo de administrador e não apenas a recebeu na visita que fez junto com o amigo Fleming como permitiu que observasse os artistas nativos no trabalho, desenhando espécimes raras de plantas. ALEXANDER, Edward Porter. Museums in motion: an introduction to the history and functions of museums. Lanham: AltaMira Press 1996, p. 146-147.

${ }^{60}$ Cf. TRAVERS, Robert. Ideology and Empire in Eighteenth-Century. The British Bengal, op. cit., p. 33,: "By 1756, Calcutta was the East India Company's most important trading post in India. Founded in the 1690s on the site of a few coastal villages by a maverick Company servant, Job Charnock, it soon became a 'presidency' town, with a governor and council, and an extensive fort complex, Fort William. In the early eighteenth century, Calcutta 1720s shipments form Bengal generally made up at least half the value of the Company's exports from India."

${ }^{61}$ Segundo Roland Lardinois a formalização da cadeira de sânscrito no College de France foi incentivada pelo ministro do interior, abade de Mostesquiou, entre 1814 e 1815. O autor atenta para concorrência no controle dos estudos orientalis- 
tas entre os eruditos franceses, britânicos e alemães e a formação de novos espaços do trabalho acadêmico nas décadas finais do século XVIII e início do XIX. LARDINOIS, Roland. L'invention de l'Inde. Entre ésotérisme et sicence. Paris: CNRS Éditions, 2007, p. 43-45, 383.

${ }^{62}$ Ver Asiatic Society em <http://asiaticsocietycal.com/history/4.htm> Acesso em 10/04/2010.

${ }^{63}$ Comenta que alguns autores substituem as duas últimas por Apabjaransa ou Jargon e Misra ou língua mista. Letters on India, p. 12.

${ }^{64}$ Idem, p. 18, 19.

${ }^{65}$ Idem, p. 19

66 "Our breakfast hour is nine o'clock, after which some one of the party reads alound till twelve, when we play an hour at whist or back-gammon. I then study till half past two, when we dress for dinner. The evening is spent Índia reading and walking as much as the short quarter-deck of our vessel will allow, and after sunset Índia conversation.” Cf. GRAHAM, Maria. Journal of a Residence in India, op. cit., p. 108.

${ }^{67}$ BAYLY, Christopher A. Empire and Information. Intelligence Gathering and Social Communication in India, 1780-1870, op. cit. ${ }^{68}$ Importante no estudo de Bayly é o controle das linhas regulares de comunicação pela Companhia e a ocupação dos postos de origem mongol. Tal quadro aponta para a existência de uma ampla malha de circulação de comunicação e conhecimento na Índia pré-colonial. Ver BAYLY, Christopher A. Imperial Meridian: the British Empire and the World, 1780-1830. London: Longman, 1989, como também CHADHURI, Kirti N. The Trading World of Asia and the English East India Company, 1660-1760. Cambridge: CambridgeUniversity Press, 1978. SOOD, Gagan D. S. The Informational Fabric of Eighteenth-Century India and the Middle East: Couriers, Intermediaries and Postal Communication. Modern Asian Studies 43,5 (2009) p. 1085-1116, apresenta uma análise acerca da organização e administração da comunicação postal na Índia pré-colonial em que se destaca o papel de organismos privados nesse setor de postagem. A autora desenvolve a interessante idéia de que uma concepção de laissez-faire marcaria o padrão de dominação dos estados na fase anterior à apropriação dessa malha de comunicação pela Companhia das Índias Orientais.

${ }^{69}$ RENDALL, Jane. The condition of women, women's writing and the Empire in nineteenth-century Britain. In HALL, Catherine e ROSE, Sonya (eds.). At Home with the Empire. Metropolitan Culture and the Imperial World. Cambridge, Cambridge University Press, 2006. p. 103.

${ }^{70}$ Cf. HALL, Catherine e ROSE, Sonya (eds.). Introduction: being at home with the Empire. Idem. Maria Graham comenta: There were a good many very pretty and very well dressed women, a few ancient belles, and at least three men for every woman. (...) After dinner the same topics continue to occupy the ladies, with the addition of lace jewels, intrigues, and the latest fashions; or, if there be any newly-arrived Young women, the making and breaking matches for them furnish employment for the ladies of the colony till the arrival of the next cargo. Journal..., p. 29.

71 "The English society of Calcutta, as it is more numerous, affords a greater variety of character, and a greater portion of intellectual refinement, than that of any other presidencies. I have met with some persons of both sexes in this place, whose benevolence attracted our affection, as their talents commanded our esteem, loved to relax form their serious occupations in the circle of their friends. Among the few here who know and appreciate these things, the most agreeable speculations are always those that point homeward to the Europe, where the mind of man seems to flourish in preference to any other land. If we look round us here, the passive submission, the apathy, and the degrading superstition of the Hindous; the more active fanaticism of the Mussulmans; the avarice, the prodigatiy, the ignorance, and the vulgarity of most of the white people, seems to place them all on a level, infinitely below that of the least refined nations of Europe." GRAHAM, Maria. Journal of a Residence in India, op. cit., p. 133, 134.

${ }^{72}$ Cf. BARROS, Carolyn A., SMITH, Johanna M. Life-writings by British women, 1660-1815: an anthology. Northeastern: Northeastern University Press, 2000.

${ }^{73}$ Cf. RENDALL, Jane, op. cit. p. 104.

${ }^{74}$ Idem.

${ }^{75}$ Cf. GONÇALVES, Margareth de Almeida. Artifício e excesso: narrativa de viagem e a visão sobre as mulheres em Portugal e Brasil. Revista Estudos Feministas, Florianópolis, v. 13, n. 3/2005; GONÇALVES, Margareth de Almeida. Viagem e escrita de si em Maria Graham. Revista Universidade Rural. Série Ciências Humanas, v. 29, 2007, p. 110-122.

${ }^{76}$ RENDALL, Jane, op. cit., p. 109.

77 PRATT, Mary. Os olhos do Império. Relatos de viagem e transculturação. Santa Catarina: EDUSC, 1999.

${ }^{78}$ Thomas Bowrey, um mercador privado inglês, deixou registro de seu contato com portugueses na região de Bengala, em Ungulim: "Um grande número de Portugueses habita no reino de Bengala, especialmente em Ugulim e noutras enseadas e ribeiros do rio. Muitos deles são filhos de Lisboa (como se designam a si próprios), ou seja, nascidos na Europa, mas muitos mais são filhos da Índia. (...) São na maioria muito pobres, mas notáveis por serem industriosos, ao viverem honestamente, e ainda mais louváveis por serem cristãos numa terra de gentios.” SUBRAHMANYAN, Sanjay. O Império Asiático Português 1500-1700. Uma história política e econômica. Lisboa, DIFEL, 1995, p. 378. 


\footnotetext{
79 "From Sion we went to Mahaim, passing in the way several neglected Portuguese churches." Maria Graham. Journal of a Residence in Índia. Op. cit., p. 8.

${ }^{80}$ Idem.

81 "Who are scraping dishes and plates with their hands, and then, with the same unwashen paws, putting aside the next day's tiffin for their master's table". Idem, p. 30.

82 "After passing slowly by Telichery, the Anjedive islands, and the picturesque point of cape Ramas, we came in sight of the fortress of Aguada, at the entrance of the harbour of Goa, and I entertained the hopes of landing the next morning to see the old city, with its marble churches and magnificent monasteries and to pay my respects to the tombo of St Francis Xavier; but a contrary breeze sprung up in the night, and blew us far from the shore, so that I was obliged to reconcile myself to the disappointment, by reflecting on the present misery of that once flourishing colony, which would have embittered any pleasure I could hope for in admiring its exterior beauties. (...) The colony is almost abandoned by the mother-country, and its inhabitants scarcely speak their native tongue intelligibly. Their poverty is such, that the women of the best families earn their subsistence by making lace, or artificial flowers, and working muslin.” Idem, p. 111.

${ }^{83}$ Idem, p. 187.
}

\section{Referências bibliográficas}

ALEXANDER, Edward Porter. Museums in motion: an introduction to the history and functions of museums. Lanham: AltaMira Press 1996.

ALMEIDA, Hermione de; GILPIN George H. Indian Renaissance: British romantic art and the prospect of India. Burlington: Ashgate, 2007.

AREND, Hannah. A condição humana. 11 ed. Rio de Janeiro: Editora Forense, 2010.

BARROS, Carolyn A.; SMITH, Johanna M. Life-writings by British women, 1660-1815: an anthology. Northeastern: Northeastern University Press, 2000.

BAYLY, Christopher A. Empire and Information. Intelligence Gathering and Social Communication in India, 17801870. Cambridge: Cambridge University Press, 1996, [Cambridge Studies in Indian History and Society].

The Birth of the modern World: 1780-1914. Global Connections and Comparison. Oxford: Blackwell, 2004.

CHADHURI, Kirti N. The Trading World of Asia and the English East India Company, 1660-1760. Cambridge: CambridgeUniversity Press, 1978

CLARKE, J. J. Oriental Enlightenment: the encounter between Asian and Western thought. Londres: Nova Iorque, Routledge, 1997.

CURTO, Diogo Ramada. Orientalistas e cronistas do Quinhentos. In: Cultura escrita. Séculos XV a XVIII. Lisboa: ICS, 2007.

FOUCAULT, Michel. Ditos e escritos III. Estética: literatura e pintura, música e cinema. Rio de Janeiro: Editora Forense Universitária, 2001.

GOLDMAN, Havey. Politics, death, and the devil: self and power in Max Weber and Thomas Mann. California: University of California Press, 1992.

GONÇALVES, Margareth de Almeida. "Artifício e excesso: narrativa de viagem e a visão sobre as mulheres em Portugal e Brasil". In: Revista Estudos Feministas, Florianópolis, v. 13, n. 3/2005, p. 613-627.

. Viagem e escrita de si em Maria Graham. In: Revista Universidade Rural. Série Ciências Humanas, v. 29, 2007, p. 110-122.

GOTCH, Rosamund Brunel. Maria Lady Callcott. The creator of “LittleArthur”. London: John Murray, 1937.

GRAHAM, Maria. Journal of a Residence in India. Edinburgh: George Ramsay and Company, 1813. [2 ed.]

. Letters on India. London: Longman, Hurst, Rees, Orme, and Brown, Paternoster-Row; Edinburgh: A. Constable and CO., 1814.

. Journal d' un séjour fait aux Indes Orientales pendant les années 1809, 1810 et 1811. Genebra/Paris: J.-J. Paschoud/ Maison de Commerce, 1818.

HABERMAS, Jürgen. Mudança estrutural da esfera pública. Rio de Janeiro, Tempo Brasileiro, 2003.

HALL, Catherine e ROSE, Sonya (eds.). At Home with the Empire. Metropolitan Culture and the Imperial World. Cambridge, Cambridge University Press, 2006. 
KOPF, David. British Orientalism and the Bengal Renaissance: the dynamics of Indian modernizaiton 1773-1835. Calcutá: Firma K. L. Mukhopadhyay, 1969.

KOSELLECK. Reinhart. historia/Historia. Madri, Editorial Trotta, 2004.

JOHNSON, Samuel. Dictionary of the English Language. Londres: J. F. and C. Rivington, L. Davis, T. Payne and Son... M. Newburt, 1785.

LARDINOIS, Roland. Linvention de l'Inde. Entre ésotérisme et sicence. Paris: CNRS Éditions, 2007.

LEASK, Nigel, Curiosity and the Aesthetics of travel writing 1770-1840. Oxford: Oxford University Press, 2002.

LEJEUNE, Philippe. L'autobiographie em France. Paris: Armand Colin, 1971.

. Le moi des demoiselles. Enquête sur le journal de jeune fille. Paris: Éditions du Seuil, 1993.

MARSHALL, P. J. (ed.). The British discovery of Hinduism in the eighteenth century. Cambridge: Cambridge University Press, 1970.

1998.

The Oxford History of the British Empire, v. II The Eighteenth Century. Oxford: Oxford University Press,

PALLARES-BURKE, Maria Lúcia Garcia. The Spectator. O teatro das luzes. Diálogo e Imprensa no século XVIII. São Paulo, Hucitec, 1995.

PHILLIPS, Mark Salber. Reconsiderations on History and Antiquarianism: Arnaldo Momigliano and the Historiography of Eighteenth-Century Britain. Journal of the History of Ideas, v. 57, n. 2, 1996, p. 297-316.

. Adam Smith and the history of private life: Social and sentimental narratives in eighteenth-century historiography. KELLEY, Donald R. e SACKS, David Harris (eds.). The Historical Imagination in Early Modern Britain: History, Rhetoric, and Fiction, 1500-1800. Cambridge: Woodrow Cambridge University Press, 2002.

POCCOCK, J. G. A. The Maquiavellian Moment. Florentine Political Thought and the Atlantic Republic Tradition. New Jersey: Princeton University Press, 1975.

. Linguagens do ideário político. São Paulo: Edusp, 2003.

PRATT, Mary. Os olhos do Império. Relatos de viagem e transculturação. Santa Catarina: EDUSC, 1999.

SCHAMA, Simon. A History of Britain 2 1603-1776. The British wars. Londres: BBC Books, 2001.

SCHOENFIELD, Mark. Novel Marriages, Romantic Labor and the Quartely Press. In: WHEATLEY, Kim. Romantic periodicals and print culture. Londres, Routledge.

SIMMEL, Georg. The ruin. In: WOLFF, Kurt. Georg Simmel: 1858-1928 (A collection of essays). Ohio: Ohio State University Press, 1959.

SOOD, Gagan D. S. The Informational Fabric of Eighteenth-Century India and the Middle East: Couriers, Intermediaries and Postal Communication. Modern Asian Studies 43,5 (2009), p. 1085-1116.

SPADAFORA, David. Progress. In KORS, Alan Charles (ed.). Encyclopedia of the Enlightenment, v. 3. Oxford: Oxford University Press, 2003.

STAFFORD, Barbara Maria. Voyage into Substance: Art, Science, Nature and the Illustrated Travel Account, 17601840. Cambridge: Cambridge Mass, MIT Press, 1984.

STORER, James; GREIG, John. Antiquarian and Topographical Cabinet, containing a series of elegant views of the most interesting objectis of curiosity in Great Britain. (vol 1) Londres, Clarke, Carpenter, Chapple, Ricahrdson, Sherwood, Neely e Jones, 1807.

SUBRAHMANYAN, Sanjay. O Império Asiático Português 1500-1700. Uma história politica e econômica. Lisboa, DIFEL, 1995.

TZOREF-ASHKENAZI, Chen. The Experienced Traveller as a Professional Author: Friedrich Ludwig Langstedt, Georg Forster and Colonialism Discourse in Eighteenth-Century Germany. History, v.95, n. 317, 2010.

TRAVERS, Robert. Ideology and Empire in Eighteenth-Century. The British Bengal. Cambridge Studies in Indian History and Society series. Cambridge: Cambridge University Press, 2007.

TRILING, Lionel. Sincerity and Authenticity. Harvard: Harvard University Press, 1972.

WHEATLEY, Kim. Romantic periodicals and print culture. Londres: Frank Cass, 2003.

WINKS, Robin (ed.). The Oxford History of the British Empire. Volume V. Historiography. Oxford: Oxford University Press, 1998. 


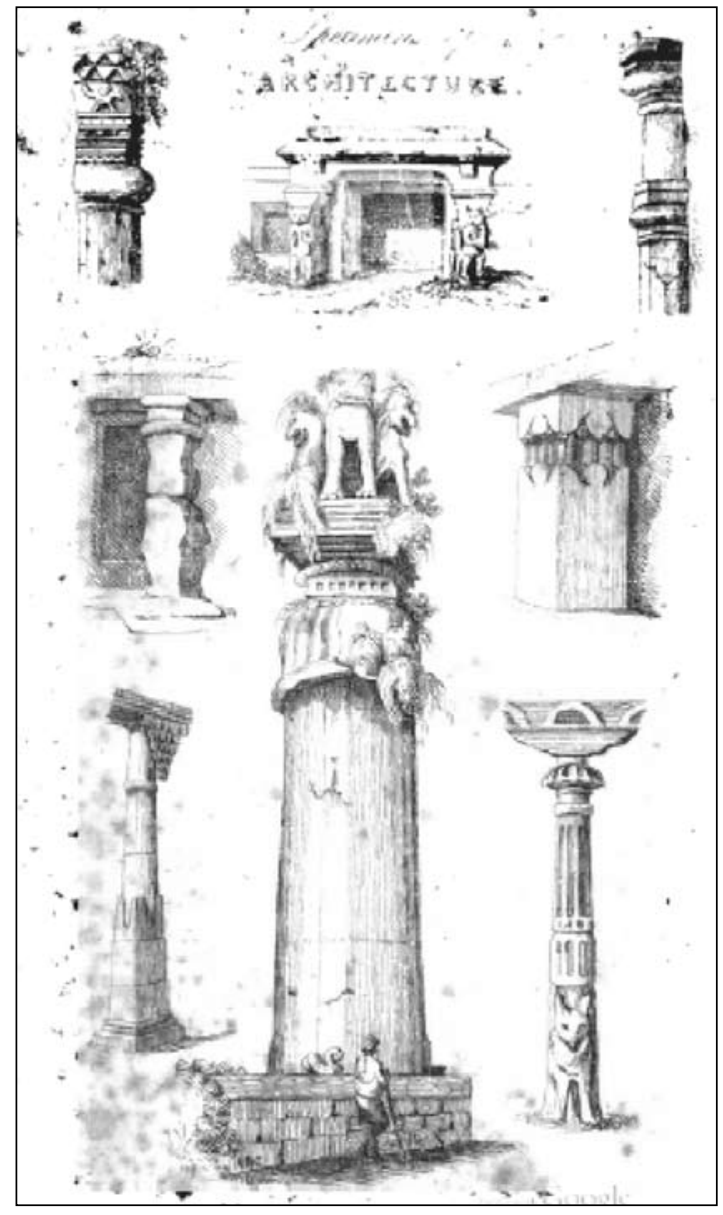

Figura 1 - Desenhos de colunas. Apud Maria Graham. Letters on India, p. 58.

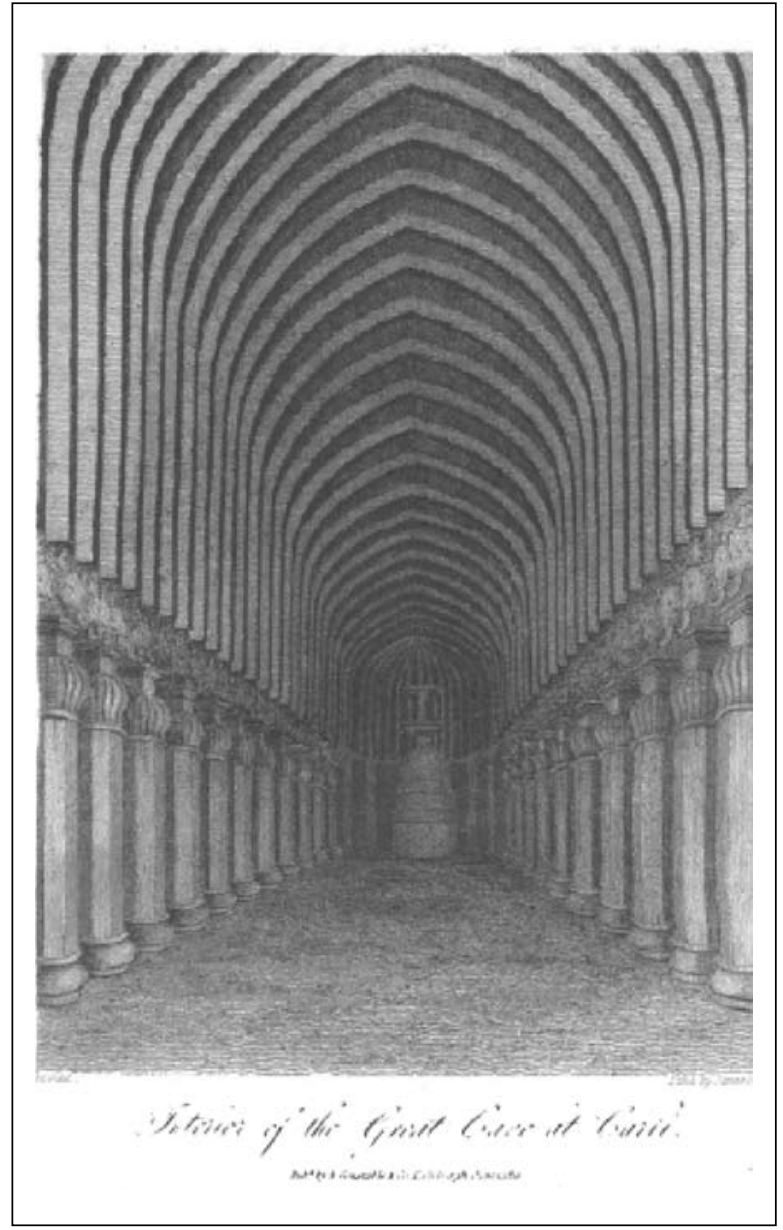

Figura 2 - Interior da Grande Gruta em Carli. Maria Graham. Journal of a Residence in India, p. 64.

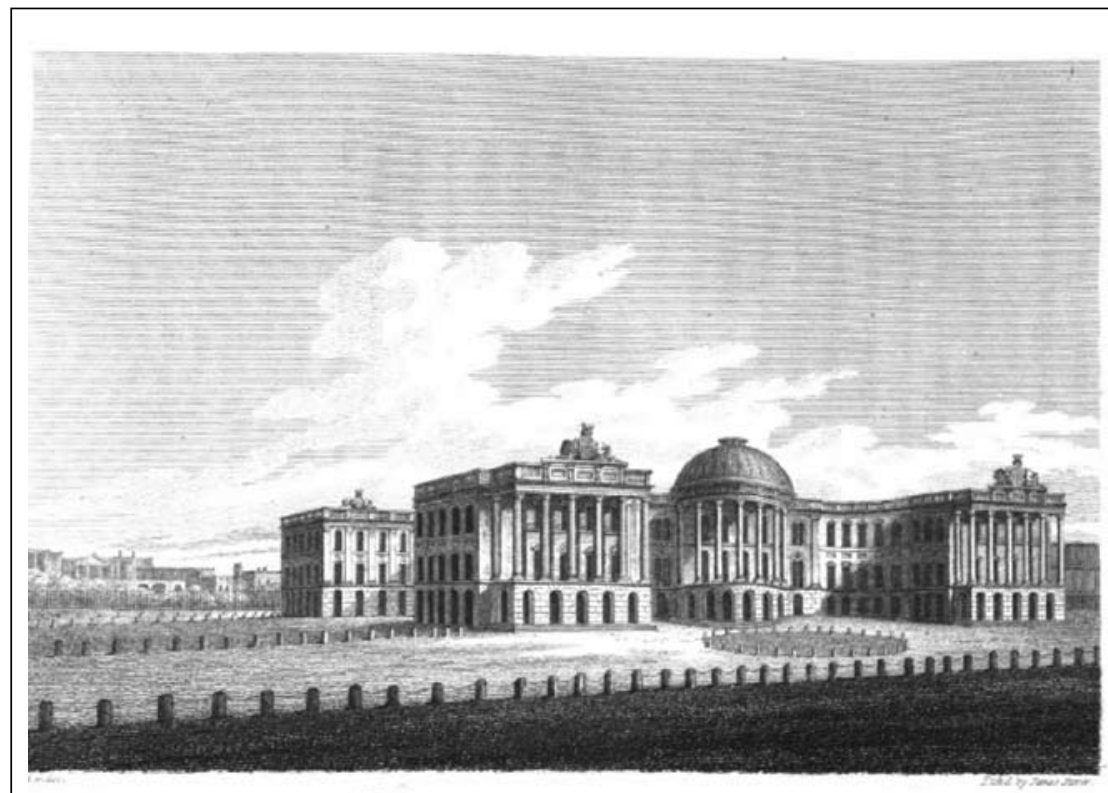

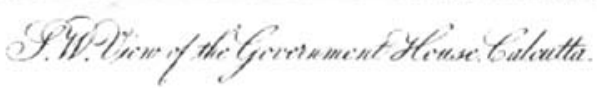

Fig. 3 - Vista do Palácio de Governo em Calcutá. Apud Maria Graham. Journal of $a$ Residence in India, p. 137. 


\section{RESUMO}

O artigo visa analisar os usos da representação do outro pela ótica das relaçôes de poder, gênero e cultura na estrutura de narrativas de viagem ao Oriente, por meio de Journal of a Residence in India e Letters on India, escritos por Maria Graham e publicados no início do século XIX. Focalizam-se as visões e as percepçōes produtoras de memória e imaginação, através da experiência da observação do viajante e de seu enquadramento aos protocolos de escrita de livros de viagem. Palavras-chave: livros de viagem; Maria Graham, India, século XIX.

\section{ABSTRACT}

This article analyzes the uses of otherness representation, from power relations, gender and culture perspectives, in the frame of travel narratives about Orient, through the books Journal of a Residence in India e Letters on India, written by Maria Graham and published at the beginning of $19^{\text {th }}$ century. The focus turns to the views and perceptions that produce memory and imagination, through the traveler experience of observing, and adherence to the writing travel books narrative protocol.

Keywords: travel books; Maria Graham, India, 19th century. 